\title{
Forced Agglutination as a Tool to Improve the Sensory Response of a Carboxylated Poly(paraphenyleneethynylene)
}

\author{
Ik-Bum Kim, Ronnie Phillips, and Uwe H. F. Bunz* \\ School of Chemistry and Biochemistry, Georgia Institute of Technology, 770 State St., \\ Atlanta, GA 30332, USA.Email: Uwe.Bunz@chemistry.gatech.edu
}

\section{Supporting Information (SI)}

Instrumentation and Materials. All chemicals and solvents were used without further purification as received unless otherwise noted. Streptavidin coated microspheres (mean diameter $=0.31 \mu \mathrm{m})$ was purchased from Bangs Laboratories, Inc. Streptavidintetramethylrhodamine conjugate and streptavidin-Texas $\operatorname{Red}^{\circledR}$ conjugate were purchased from Molecular Probes. Avidin ( $\mathrm{MW}=66,000)$ was purchased from Sigma-Aldrich Co and streptavidin was purchased from Fluka. Fluorescence data were obtained with a Shimadzu RF5301PC spectrofluorophotometer in quartz cuvettes. PPE 1 was synthesized previously ${ }^{1}$ and had the number average molecular weight of 12,000 with a polydispersity $(\mathrm{Mw} / \mathrm{Mn})$ of 4.3 . The excitation wavelength was $425 \mathrm{~nm}$ (or $405 \mathrm{~nm}$ ) and the emission was recorded from $440 \mathrm{~nm}$ (or $420 \mathrm{~nm}$ ) to $650 \mathrm{~nm}$. Solutions of PPE 1 (SS1), PPE 3 (SS3), and PPE 4 (SS4) were prepared in $0.1 \mathrm{M}$ sodium phosphate buffer $(\mathrm{pH}=7.2)$ with a concentration of $1 \mathrm{mg} / \mathrm{L}$. In each quenching experiment, a small aliquot $(20-100 \mu \mathrm{L})$ of concentrated quencher solution was added to $5 \mathrm{~mL}$ of diluted fluorophore solution by using a calibrated microliter pipet. The fluorescence was recorded at room temperature.

\section{Synthesis of Polymers (2 - 4)}

Monomers (2a-2c): Synthesis of $\mathbf{2 a}$, 2b, and 2c were described in our previous reports. ${ }^{1,2}$ Synthesis of Polymer (2): Monomer 2a (222 mg, $0.30 \mathrm{mmol}), 2 \mathbf{b}(160 \mathrm{mg}, 0.30 \mathrm{mmol})$, and 2c $(218 \mathrm{mg}, 0.66 \mathrm{mmol})$ were dissolved in a mixture of triethylamine $(1 \mathrm{~mL})$, and DMF $(5 \mathrm{~mL})$ in a Schlenk flask $(25 \mathrm{~mL})$ under a flow of nitrogen and with magnetic stirring. $\left(\mathrm{Ph}_{3} \mathrm{P}\right)_{2} \mathrm{PdCl}_{2}(2.0$ $\mathrm{mg}, 2.8 \mu \mathrm{mol})$ and $\mathrm{CuI}(0.5 \mathrm{mg}, 2.8 \mu \mathrm{mol})$ were added to the flask. The reaction mixture was stirred at room temperature for $24 \mathrm{~h}$. The solution was slowly added to ether $(200 \mathrm{~mL})$. The precipitate was washed with ether and water. A yellow solid was obtained in $99 \%$ yield (421 $\mathrm{mg}$ ). PPE 4 shows an absorption maximum at $436 \mathrm{~nm}$ and an emission maximum at $470 \mathrm{~nm}$ in chloroform, typical for a dialkoxy-PPE. The number average molecular weight $\left(\mathrm{M}_{\mathrm{n}}\right)$ of $\mathbf{4}$ is 8,300 with a polydispersity index of 1.70 (GPC, polystyrene standard). ${ }^{1} \mathrm{H}$ NMR (DMSO-d 6 ): $\delta 7.14$, 4.92, 4.19, 3.56, 3.49, 3.09, 1.21 .

Synthesis of Polymer (3): Polymer $\underline{\mathbf{2}}(60 \mathrm{mg}, 0.04 \mathrm{mmol})$ was dissolved in DMF (7 mL) in a flask $(25 \mathrm{~mL})$ under a flow of nitrogen and with magnetic stirring. D-biotin $(25 \mathrm{mg}, 0.10 \mathrm{mmol})$, TMP (12 mg, $0.10 \mathrm{mmol})$, and $\mathrm{EDC} \cdot \mathrm{HCl}(20 \mathrm{mg}, 0.10 \mathrm{mmol})$ were added to the flask in an ice bath. The reaction mixture was stirred at room temperature for $24 \mathrm{~h}$. The solvent was 
evaporated under a reduced pressure. Methanol $(20 \mathrm{~mL})$ and $\mathrm{NaOH}(200 \mathrm{mg}, 5 \mathrm{mmol})$ were added to the reaction mixture and the temperature was increased to $40{ }^{\circ} \mathrm{C}$. The mixture was stirred for $24 \mathrm{hr}$. The reaction flask was stored in a refrigerator overnight. The precipitate was collected and washed with methanol and acetone. An orange solid $(67 \mathrm{mg})$ was obtained. ${ }^{1} \mathrm{H}$ NMR $\left(\mathrm{D}_{2} \mathrm{O}\right): \delta 6.81,4.49,3.35,3.05,2.85,2.71,2.51,1.91$.

Synthesis of Polymer (4): Polymer 2 (60 mg, $0.04 \mathrm{mmol})$ and $\mathrm{NaOH}(200 \mathrm{mg})$ were dissolved in $\mathrm{MeOH}(25 \mathrm{~mL})$ in a flask $(50 \mathrm{~mL})$ with magnetic stirring. The reaction mixture was stirred at $40{ }^{\circ} \mathrm{C}$ for $48 \mathrm{~h}$. The reaction flask was stored in a refrigerator overnight. The precipitate was collected and washed with methanol and acetone. An orange solid (48 mg) was obtained. ${ }^{1} \mathrm{H}$ $\operatorname{NMR}\left(\mathrm{D}_{2} \mathrm{O}\right): \delta 6.70,4.40,3.23$.

Scheme 1. Synthesis of biotin-substituted PPE 3 by post-functionalization of PPE 2.

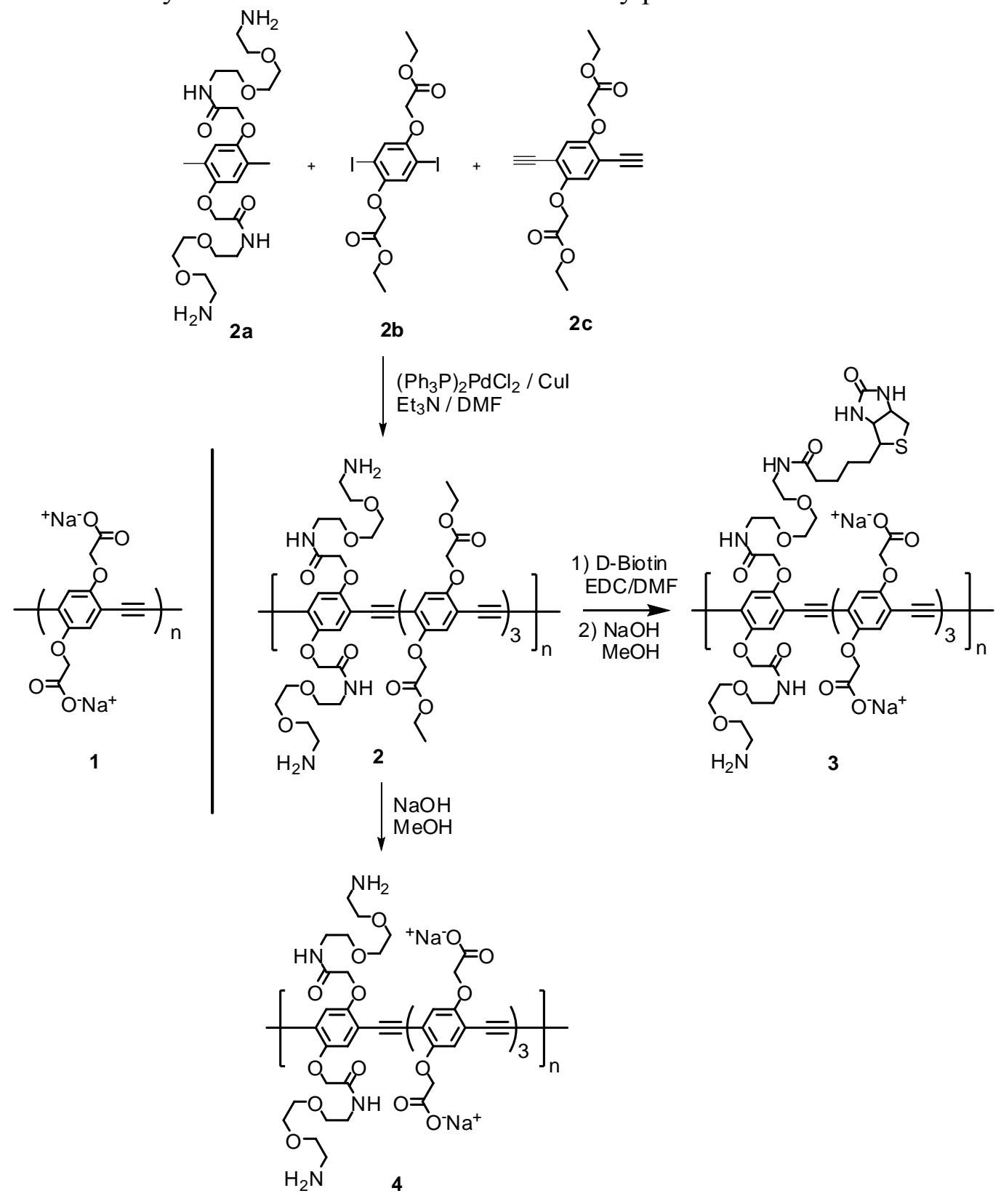




\section{Experiment 1. Influence of 10 different metal ions on the optical properties of PPE 3 in 0.1 M phosphate buffer solution at $\mathbf{p H}=\mathbf{7 . 2}$.}

To investigate the sensory ability of 3 toward metal ions, we exposed this polymer to concentrated solutions of metal ions in a $0.1 \mathrm{M}$ phosphate buffer solution $(\mathrm{pH}=7.2)$. The concentration of PPE 3 (SS3) was adjusted to $1 \mathrm{mg} / \mathrm{L}$ in a phosphate buffer solution. Solutions of 10 metal salts were prepared at a $0.1 \mathrm{M}$ concentration: They are $\mathrm{Zn}\left(\mathrm{ClO}_{4}\right)_{2}, \mathrm{CdCl}_{2}, \mathrm{Hg}(\mathrm{O}-\mathrm{CO}-$ $\left.\mathrm{CF}_{3}\right)_{2}, \mathrm{~Pb}\left(\mathrm{NO}_{3}\right)_{2}, \mathrm{FeCl}_{3}, \mathrm{NiCl}_{2}, \mathrm{CoCl}_{2}, \mathrm{CuBr}_{2}, \mathrm{Ca}\left(\mathrm{NO}_{3}\right)_{2}$, and $\mathrm{Mg}(\mathrm{OTf})_{2} .20 \mu \mathrm{L}$ of each metal ion solution was added to $5 \mathrm{~mL}$ of a buffered solution of SS3. The concentration of each metal ion is $4 \times 10^{-4} \mathrm{M}$ in a buffered solution of SS3.

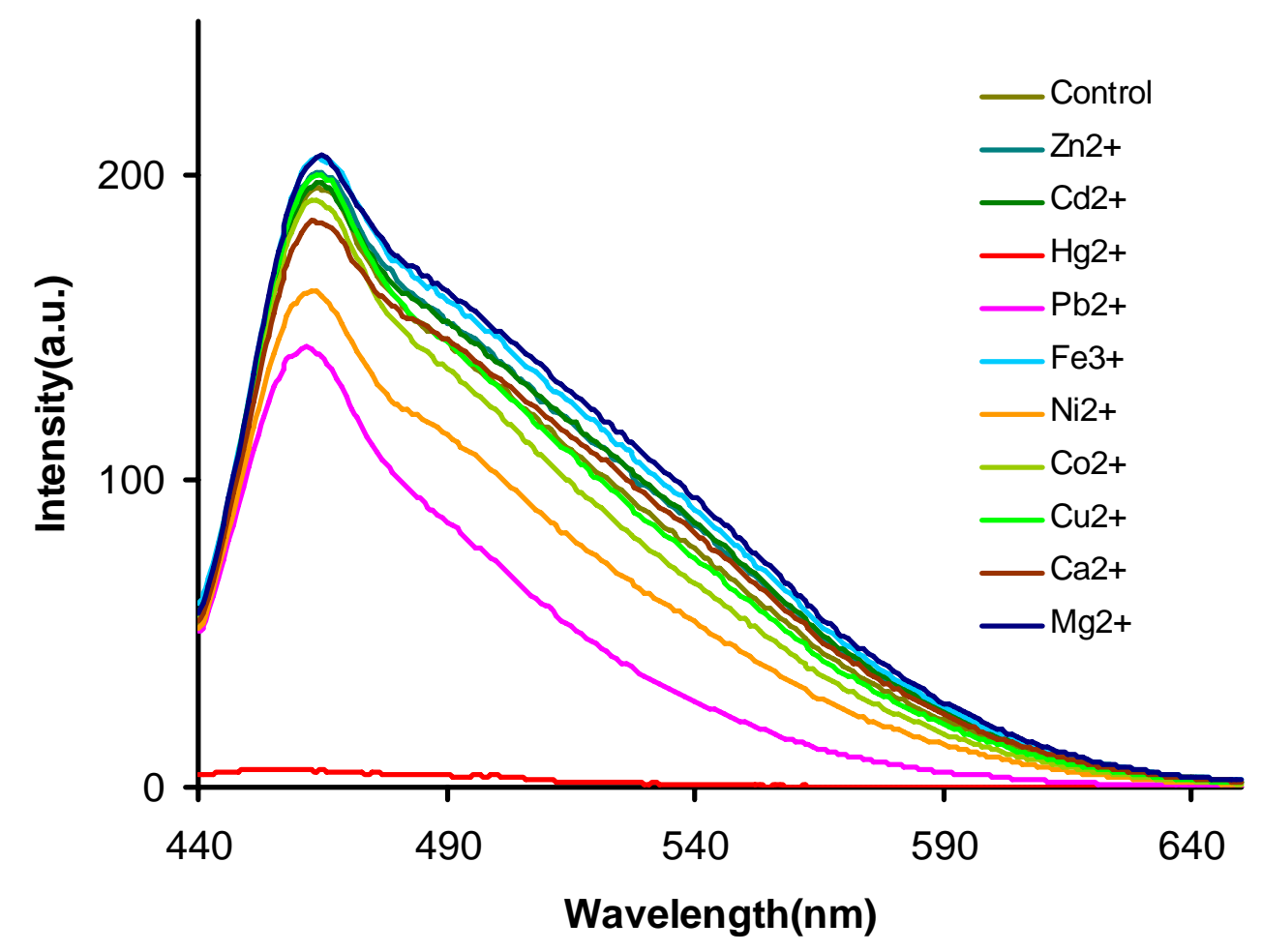

Figure 1. Emission spectra of solutions of PPE $\underline{\mathbf{3}}$ by addition of $20 \mu \mathrm{L}$ of a $0.4 \mathrm{mM}$ solution of metal ions. Spectra show significant quenching with $\mathrm{Hg}^{2+}$ ions.

Most metal cations showed slight effects while mercury showed a substantial quenching of the fluorescence at a concentration of $4 \times 10^{-4} \mathrm{M}$. While $\mathrm{Pb}^{2+}$ ions showed mild quenching in diluted solution of $3, \mathrm{Hg}^{2+}$ ions showed large quenching in a concentrated solution of $\mathbf{3}$ immediately after the addition of mercury ions. 
Experiment 2. Concentration dependent quenching of the fluorescence of PPE 3 by the addition of mercury ions.

A small aliquot (10-100 $\mu \mathrm{L})$ of concentrated solutions of $\mathrm{Hg}\left(\mathrm{O}-\mathrm{CO}-\mathrm{CF}_{3}\right)_{2}\left(1 \times 10^{-3} \mathrm{M}\right.$ and $1 \times 10^{-2}$ $\mathrm{M})$ was added to each vial containing $5 \mathrm{~mL}$ of SS3. The concentration of $\mathrm{Hg}\left(\mathrm{O}-\mathrm{CO}-\mathrm{CF}_{3}\right)_{2}$ in SS3 is $2-200 \mu \mathrm{M}$. In SS3, the apparent Stern-Volmer constant $\left(\mathrm{K}_{\mathrm{sv}}\right)$ for $\mathrm{Hg}^{2+}$ ions is $1.0 \times 10^{4} \mathrm{M}^{-1}$. $\mathrm{Ksv}$ of $\mathbf{3}$ for $\mathrm{Hg}^{2+}$ ions is similar to that of $\mathbf{1}$.

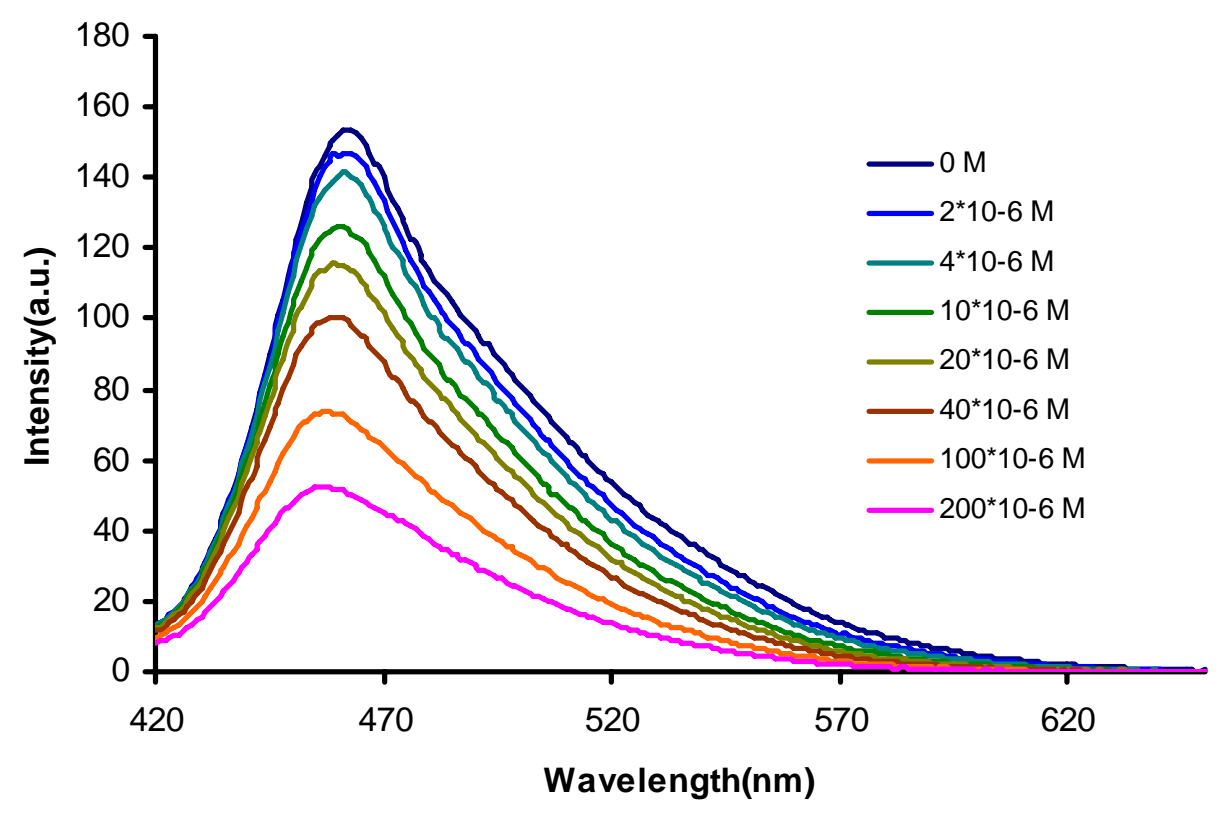

Figure 2. Emission spectra of solutions of $\mathbf{3}$ by addition of increasing concentrations of mercury ions.

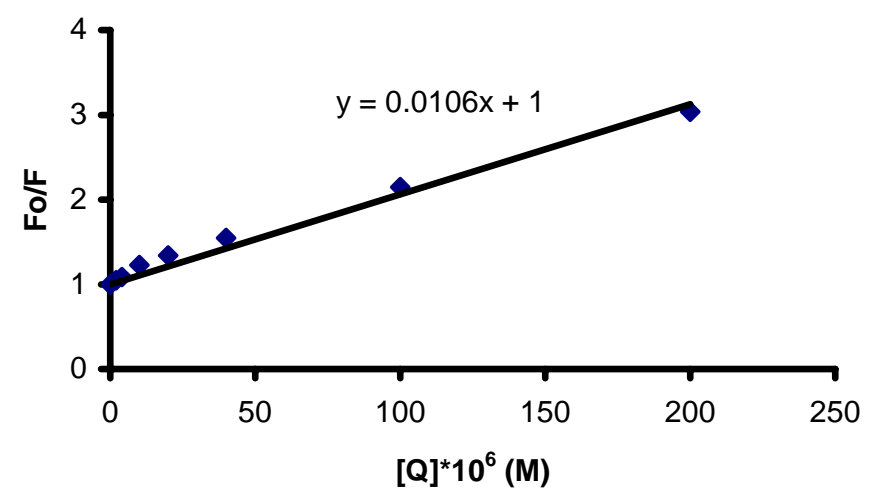

Figure 3. Fo/F plots for 3 with mercury ions. The apparent Stern-Volmer constant $\left(\mathrm{K}_{\mathrm{sv}}\right)$ for $\mathrm{Hg}^{2+}$ ions is $1.0 \times 10^{4} \mathrm{M}^{-1}$. 
Experiment 3. Influence of streptavidin coated microspheres on the optical properties of PPE 3 in $0.1 \mathrm{M}$ phosphate buffer solution at $\mathbf{p H}=7.2$.

$5-50 \mu \mathrm{L}$ of a solution of streptavidin coated microspheres (SCM, Bangs Laboratories catalog code $\mathrm{CP} 01 \mathrm{~B}$, mean diameter $=0.31 \mu \mathrm{m}$ ) were added to a buffered solution of SS3. The fluorescence intensities of SS3 were decreased by increasing concentration of SCM, indicating the formation of an agglutination.

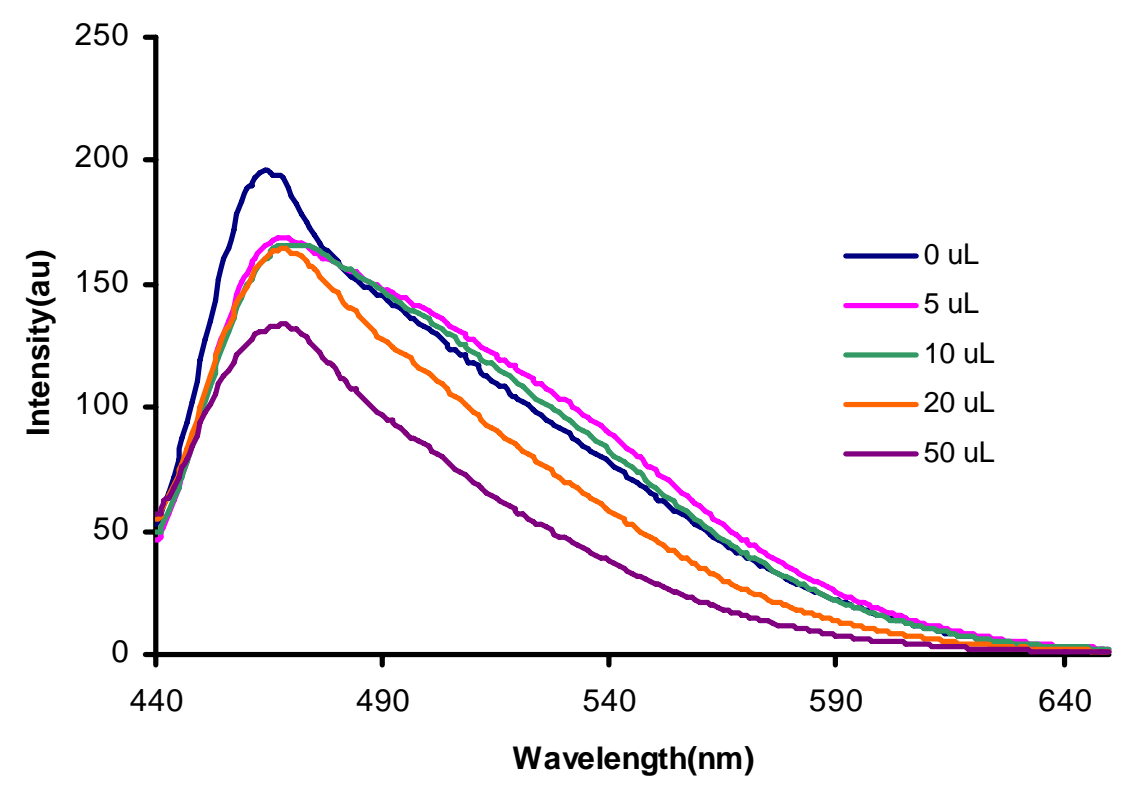

Figure 4. Emission spectra of solutions of $\mathbf{3}$ by addition of increasing concentrations of streptavidin coated microspheres (SCM). 
Experiment 4. Influence of 10 different metal ions on the optical properties of PPE 3streptavidin coated microspheres in $0.1 \mathrm{M}$ phosphate buffer solution at $\mathbf{p H}=7.2$.

$5 \mathrm{uL}$ of SCM was added to $5 \mathrm{~mL}$ of SS3 to form a lightly pre-agglutinated solution of 3-SCM. The pre-agglutinated solutions of 3-SCM were exposed to 10 different metal ions. Solutions of 10 metal salts were prepared at a $0.1 \mathrm{M}$ concentration: They are $\mathrm{Zn}\left(\mathrm{ClO}_{4}\right)_{2}, \mathrm{CdCl}_{2}, \mathrm{Hg}(\mathrm{O}-\mathrm{CO}-$ $\left.\mathrm{CF}_{3}\right)_{2}, \mathrm{~Pb}\left(\mathrm{NO}_{3}\right)_{2}, \mathrm{FeCl}_{3}, \mathrm{NiCl}_{2}, \mathrm{CoCl}_{2}, \mathrm{CuBr}_{2}, \mathrm{Ca}\left(\mathrm{NO}_{3}\right)_{2}$, and $\mathrm{Mg}(\mathrm{OTf})_{2} .20 \mu \mathrm{L}$ of each metal ion solution was added to $5 \mathrm{~mL}$ of a buffered solution of 3-SCM. The concentration of each metal ion is $4 \times 10^{-4} \mathrm{M}$ in a buffered solution of 3-SCM. Most of the metal ions showed similar quenching effects while $\mathrm{Ca}$ ions showed significant quenching unlike 3.

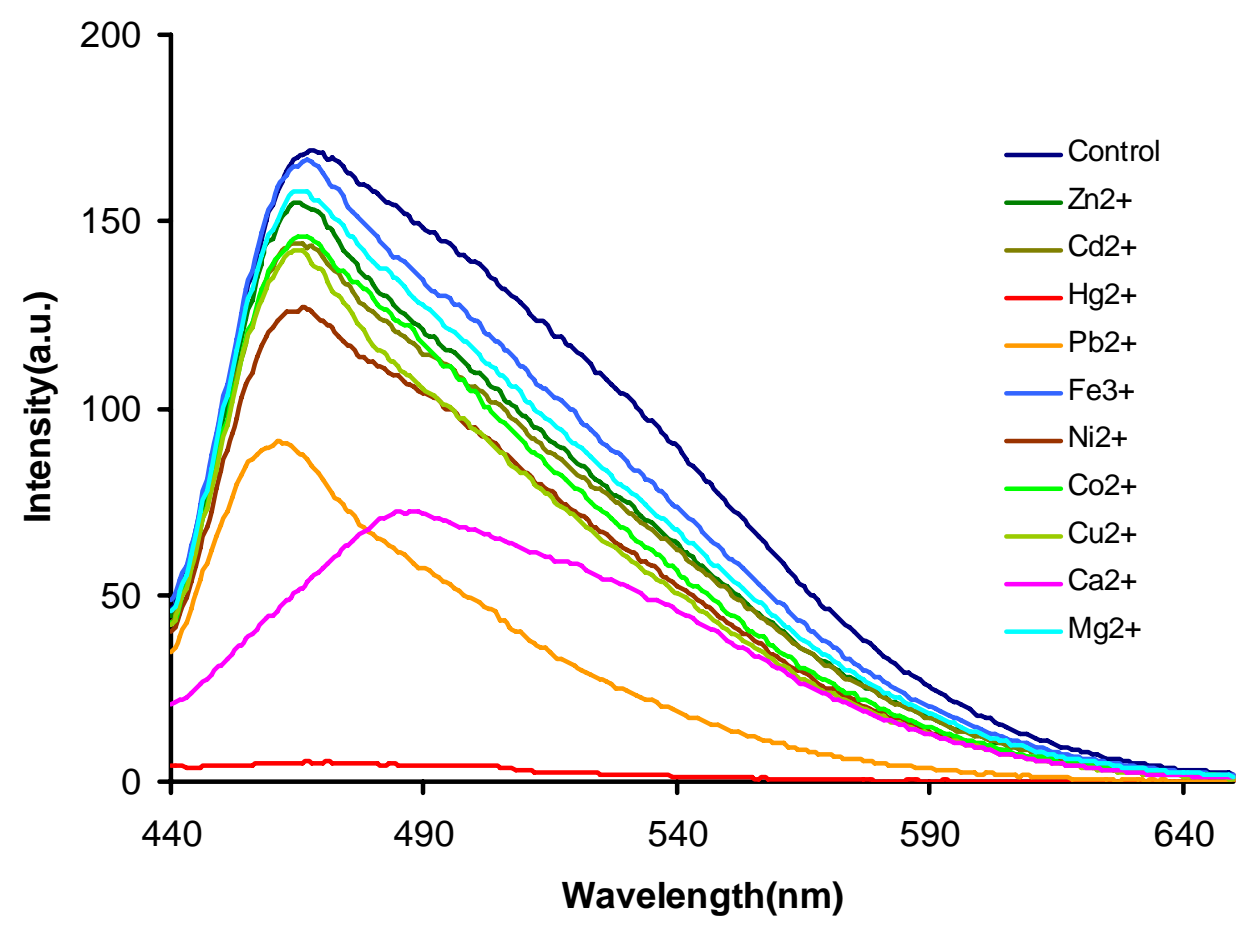

Figure 5. Emission spectra of solutions of 3-SCM complexes by addition of $20 \mu \mathrm{L}$ of a $0.4 \mathrm{mM}$ solution of metal ions. Spectra show significant quenching with $\mathrm{Ca}^{2+}$ ions and $\mathrm{Hg}^{2+}$ ions. 
Experiment 5. Concentration dependent quenching of the fluorescence of PPE 3streptavidin coated microspheres complexes by the addition of mercury ions.

\section{A) Partially complexed solution of 3 with SCM}

$5 \mathrm{uL}$ of a solution of streptavidin coated microspheres was added to $5 \mathrm{~mL}$ of SS3. In 3-SCM complexes, the apparent Stern-Volmer constant $\left(\mathrm{K}_{\mathrm{sv}}\right)$ for $\mathrm{Hg}^{2+}$ ions is $4.8 \times 10^{4} \mathrm{M}^{-1} . \mathrm{K}_{\mathrm{Sv}}$ for 3SCM is four times increased when compared to that observed for $\mathbf{3}$ alone.

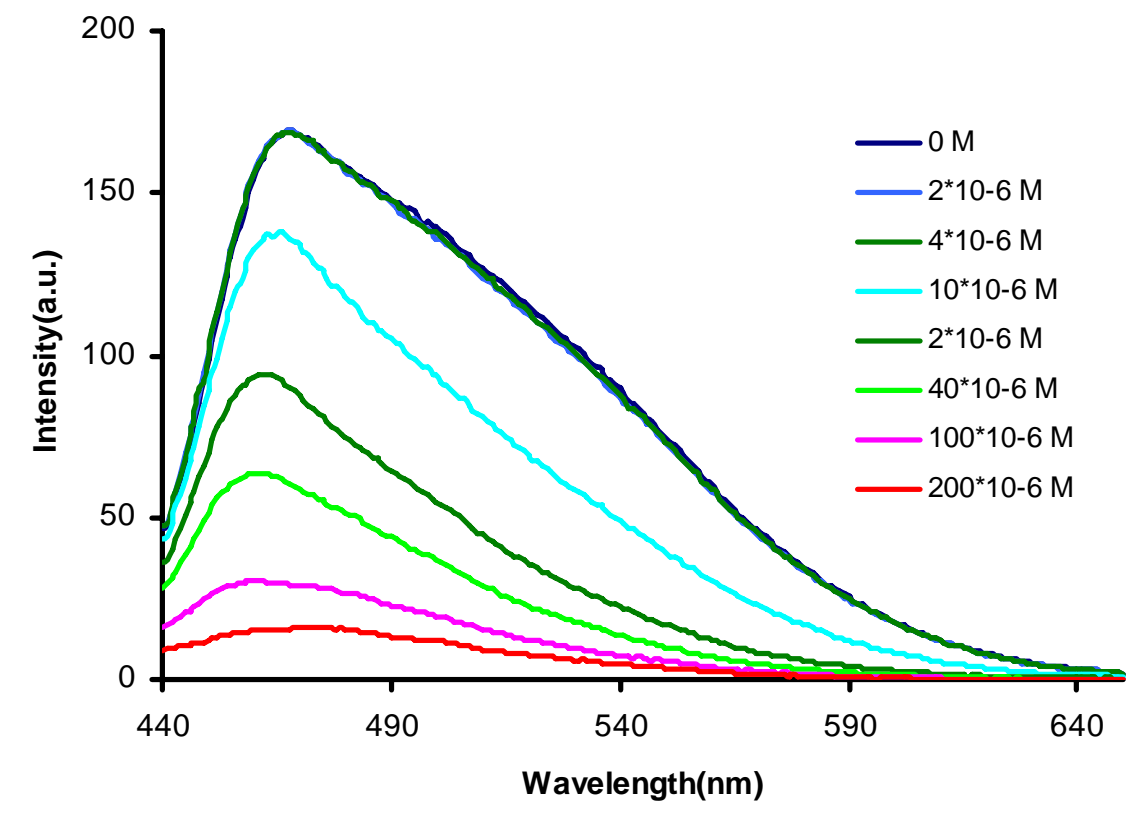

Figure 6. Emission spectra of solutions of 3-SCM complexes by addition of increasing concentrations of mercury ions.

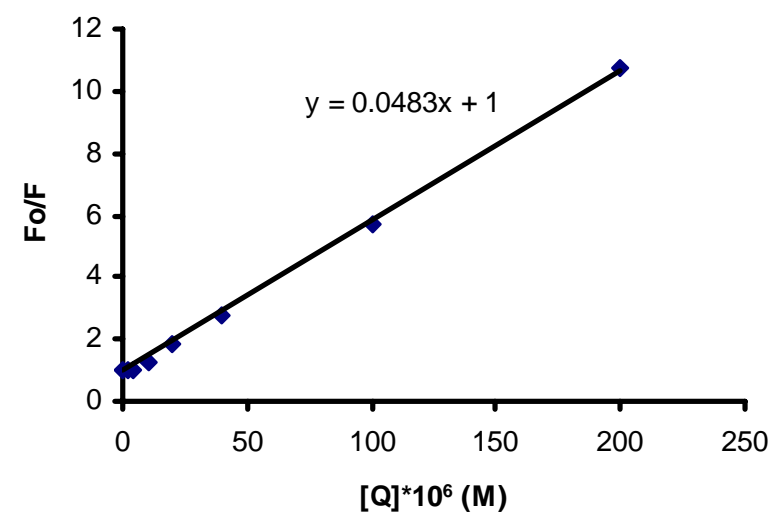

Figure 7. Fo/F plots for 3-SCM complexes with mercury ions. The apparent Stern-Volmer constant $\left(\mathrm{K}_{\mathrm{sv}}\right)$ for $\mathrm{Hg}^{2+}$ ion is $4.8 \times 10^{4} \mathrm{M}^{-1}$. 


\section{B) Fully complexed solution of 3 with SCM}

$100 \mathrm{uL}$ of a streptavidin coated microspheres solution was added to $100 \mathrm{~mL}$ of SS3. The solution was centrifuged and the supernatant was decanted. $0.1 \mathrm{M}$ phosphate buffer solution was added to the precipitate. This process was repeated three times. The precipitate was diluted with $0.1 \mathrm{M}$ phosphate buffer and the solution was sonicated. In 3-SCM complexes, the apparent SternVolmer constant $\left(\mathrm{K}_{\mathrm{sv}}\right)$ based on the linear part of the curve for $\mathrm{Hg}^{2+}$ ions is $7.2 \times 10^{4} \mathrm{M}^{-1}$.

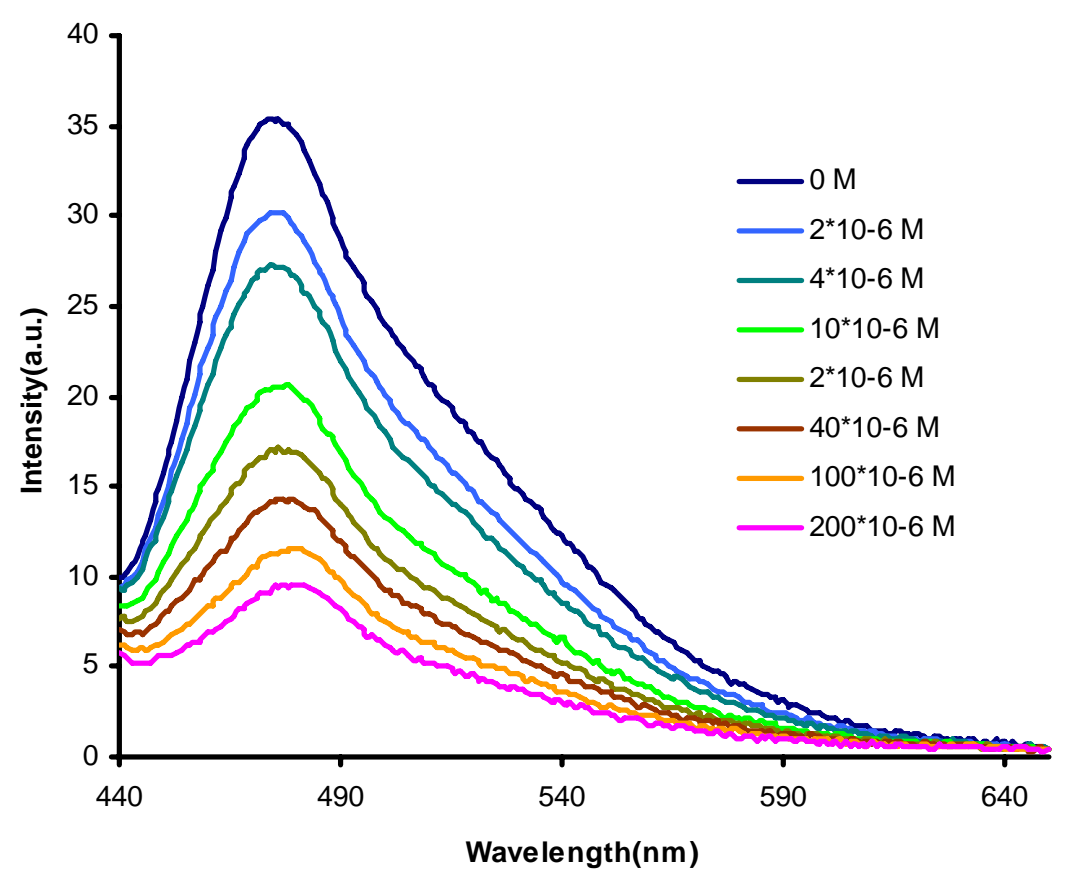

Figure 8. Emission spectra of solutions of 3-SCM complexes by the addition of increasing concentrations of mercury ions.
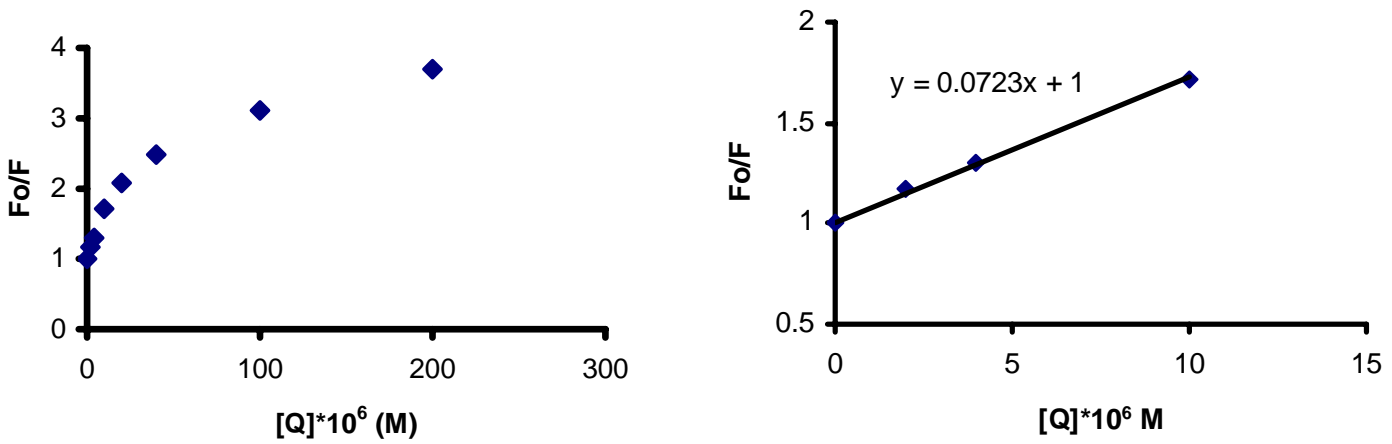

Figure 9. Fo/F plots for 3-SCM complexes with mercury ions. The apparent Stern-Volmer constant $\left(\mathrm{K}_{\mathrm{sv}}\right)$ for $\mathrm{Hg}^{2+}$ ions based on initial linear parts is $7.2 \times 10^{4} \mathrm{M}^{-1}$. 


\section{Experiment 6. Quenching of the fluorescence of 3 by avidin.}

A small aliquot $(20-500 \mu \mathrm{L})$ of concentrated solutions of avidin $\left(1.5 \times 10^{-6} \mathrm{M}\right)$ was added to each vial containing $5 \mathrm{~mL}$ of SS3. The concentration of avidin in SS3 is $6-150 \mathrm{nM}$. The apparent Stern-Volmer constant $\left(\mathrm{K}_{\mathrm{sv}}\right)$ based on the linear part of the curve for avidin is $33 \times 10^{6} \mathrm{M}^{-1}$.

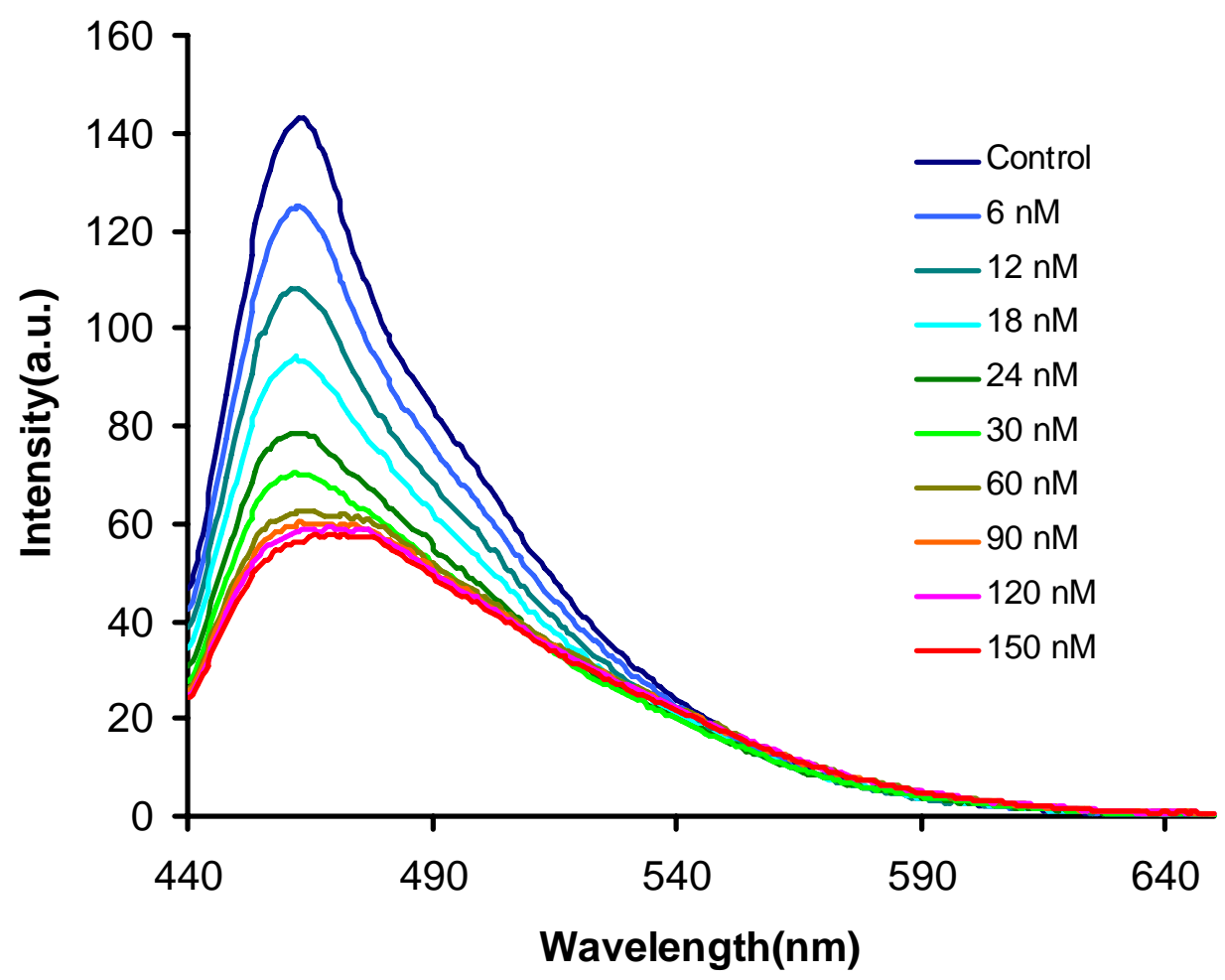

Figure 10. Emission spectra of solutions of $\mathbf{3}$ by addition of increasing concentrations of avidin.
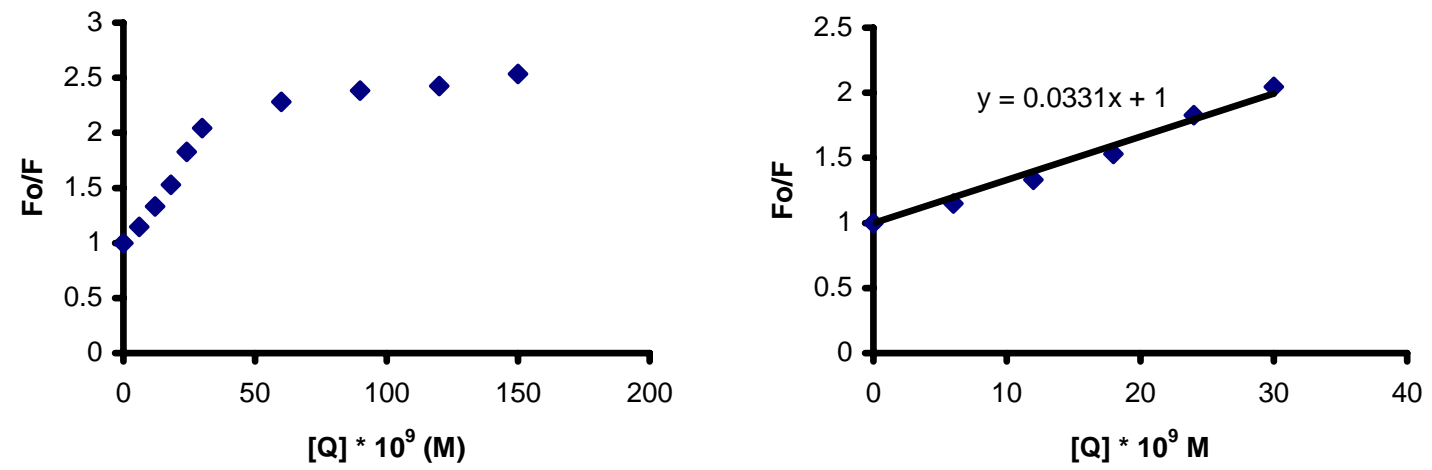

Figure 11. Fo/F plots for 3 with avidin. The apparent Stern-Volmer constant $\left(\mathrm{K}_{\mathrm{sv}}\right)$ for avidin based on initial linear parts is $33 \times 10^{6} \mathrm{M}^{-1}$. 


\section{Experiment 7. Quenching of the fluorescence of $\mathbf{3}$ by streptavidin-tetramethylrhodamine conjugate.}

A small aliquot (20-500 $\mu \mathrm{L})$ of concentrated solutions of streptavidin-tetramethylrhodamine conjugate $\left(1.5 \times 10^{-6} \mathrm{M}\right)$ was added to each vial containing $5 \mathrm{~mL}$ of SS3. The concentration of streptavidin-tetramethylrhodamine conjugate in SS3 is $6-150 \mathrm{nM}$. The apparent Stern-Volmer constant $\left(\mathrm{K}_{\mathrm{sv}}\right)$ based on the linear part of the curve for the streptavidin-tetramethylrhodamine conjugate is $28 \times 10^{6} \mathrm{M}^{-1}$. We observed a slight increase of fluorescence due to the fluorescence resonance energy transfer process from PPE to tetramethylrhodamine. Without 3 , same concentration of streptavidin-tetramethylrhodamine conjugate showed no distinct emission.

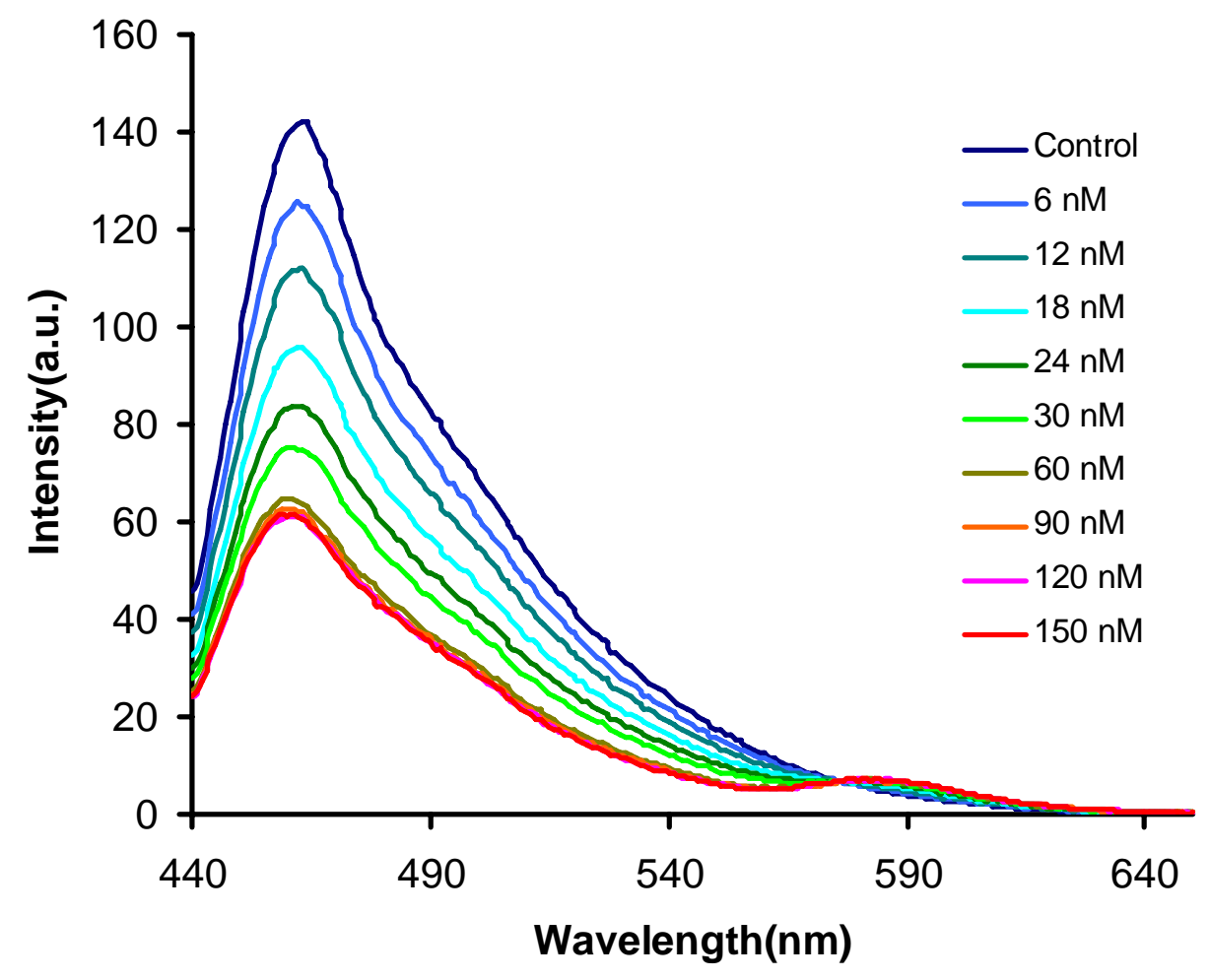

Figure 12. Emission spectra of solutions of $\mathbf{3}$ by addition of increasing concentrations of streptavidintetramethylrhodamine conjugate. 

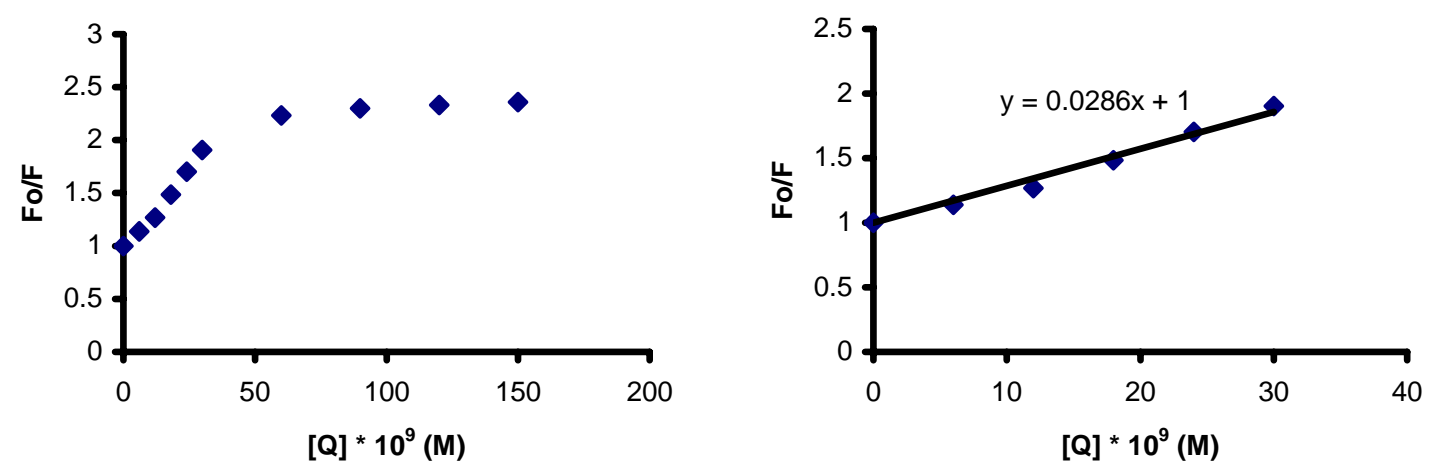

Figure 13. Fo/F plots for 3 with streptavidin- tetramethylrhodamine conjugate. The apparent Stern-Volmer constant $\left(\mathrm{K}_{\mathrm{sv}}\right)$ for streptavidin- tetramethylrhodamine conjugate based on initial linear parts is $28 \times 10^{6} \mathrm{M}^{-1}$.

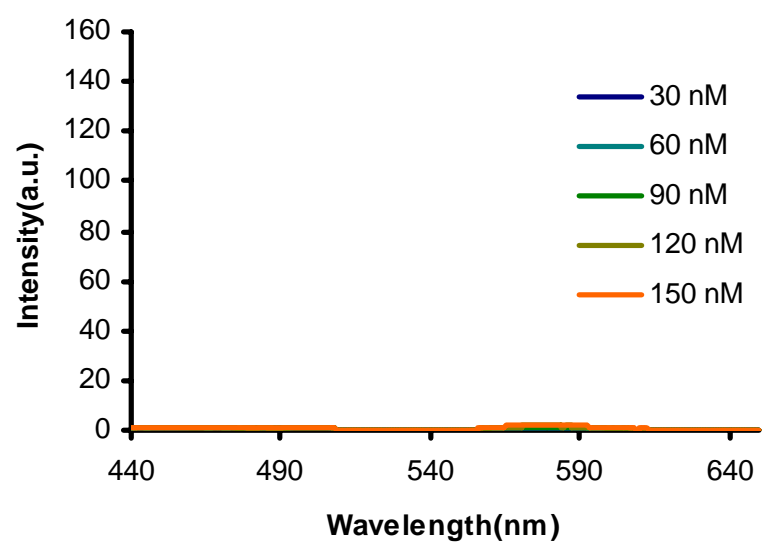

Figure 14. Emission spectra of increasing concentrations of streptavidin-tetramethylrhodamine conjugate. 


\section{Experiment 8. Quenching of the fluorescence of 3 by streptavidin-Texas Red conjugate.}

A small aliquot (20-500 $\mu \mathrm{L})$ of concentrated solutions of streptavidin-Texas Red conjugate $\left(1.5 \times 10^{-6} \mathrm{M}\right)$ was added to each vial containing $5 \mathrm{~mL}$ of SS3. The concentration of streptavidinTexas Red conjugate in SS3 is $6-150 \mathrm{nM}$. The apparent Stern-Volmer constant $\left(\mathrm{K}_{\mathrm{sv}}\right)$ based on the linear part of the curve for the streptavidin-Texas Red conjugate is $9 \times 10^{6} \mathrm{M}^{-1}$. We observed a slight increase of fluorescence due to the fluorescence resonance energy transfer process from PPE to Texas Red. The FRET efficiency in streptavidin-Texas Red is greater than that in streptavidin-tetramethylrhodamine conjugate. Without 3, same concentration of streptavidinTexas Red conjugate showed no distinct emission.

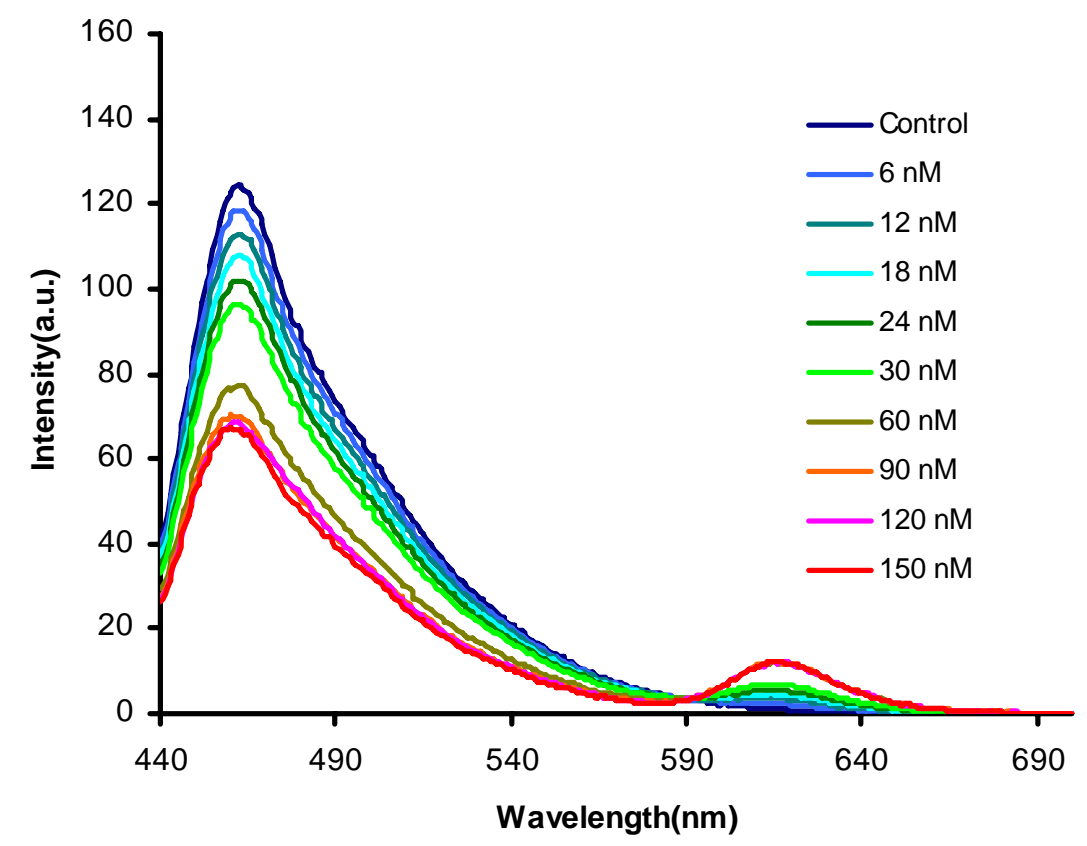

Figure 15. Emission spectra of solutions of $\mathbf{3}$ by addition of increasing concentrations of streptavidinTexas Red conjugate.
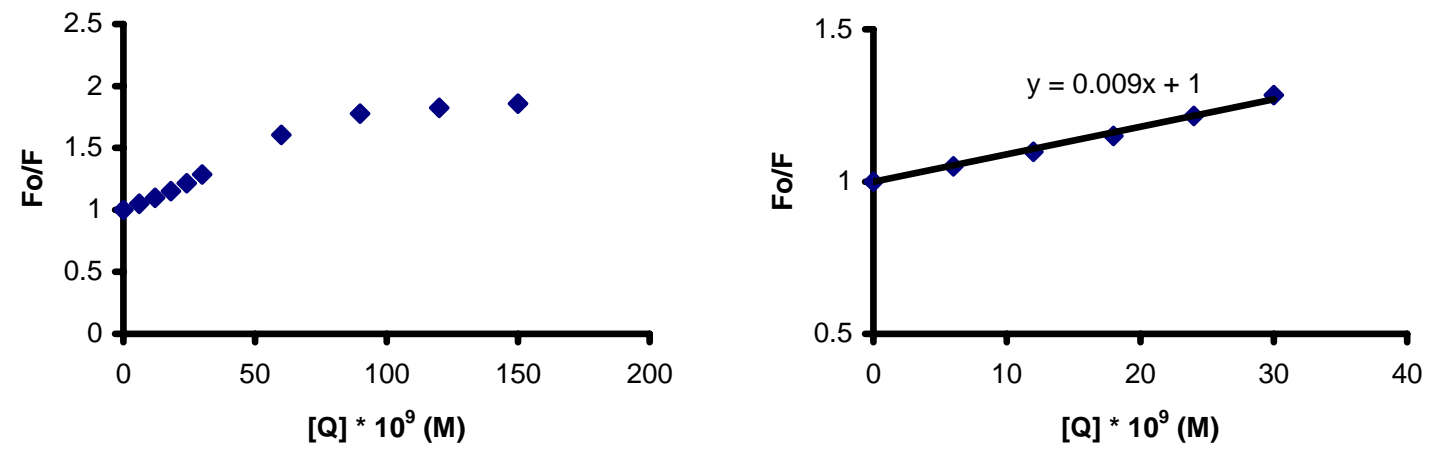

Figure 16. Fo/F plots for 3 with streptavidin-Texas Red conjugate. The apparent Stern-Volmer constant $\left(K_{\mathrm{sv}}\right)$ for streptavidin-Texas Red conjugate based on initial linear parts is $9 \times 10^{6} \mathrm{M}^{-1}$. 


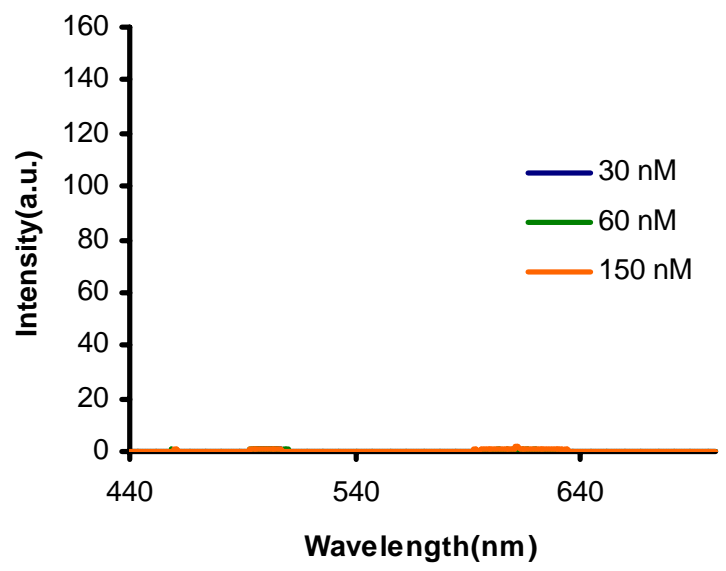

Figure 17. Emission spectra of increasing concentrations of streptavidin-Texas Red conjugate. 
Experiment 9. Concentration dependent quenching of the fluorescence of 3-avidin complexes by added mercury ions.

A solution of avidin was added to SS3 resulting in a $30 \mathrm{mM}$ avidin solution concentration. A small aliquot $(10-100 \mu \mathrm{L})$ of concentrated solutions of $\mathrm{Hg}\left(\mathrm{O}-\mathrm{CO}-\mathrm{CF}_{3}\right)_{2}\left(1 \times 10^{-3} \mathrm{M}\right.$ and $\left.1 \times 10^{-2} \mathrm{M}\right)$ was added to each vial containing $5 \mathrm{~mL}$ of a 3 -avidin solution. The concentration of $\mathrm{Hg}(\mathrm{O}-\mathrm{CO}-$ $\left.\mathrm{CF}_{3}\right)_{2}$ in 3-avidin solution is $2-200 \mu \mathrm{M}$. In 3-avidin complexes, the apparent Stern-Volmer constant $\left(\mathrm{K}_{\mathrm{sv}}\right)$ for $\mathrm{Hg}^{2+}$ ions is $1.1 \times 10^{5} \mathrm{M}^{-1}$.

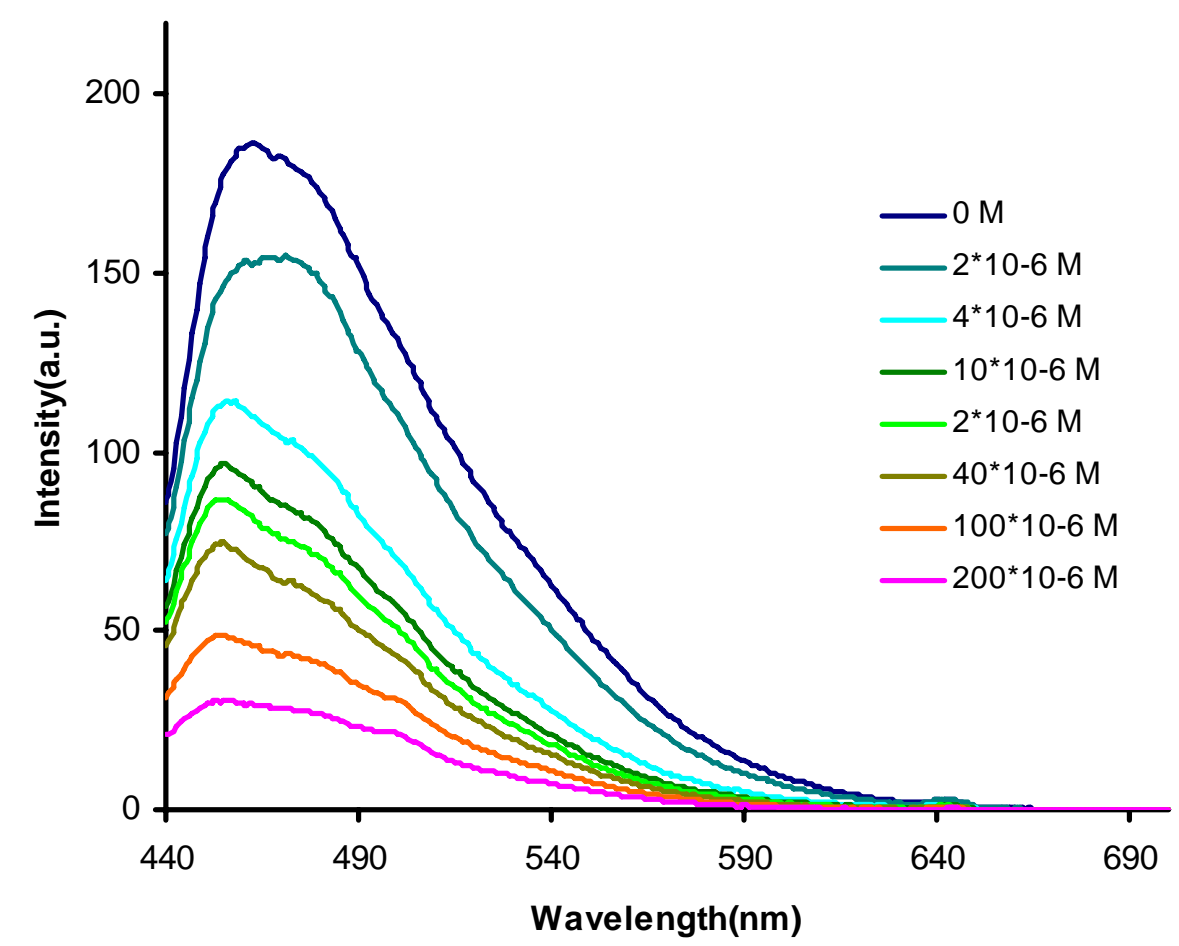

Figure 18. Emission spectra of solutions of 3-avidin complexes by addition of increasing concentrations of mercury ions.
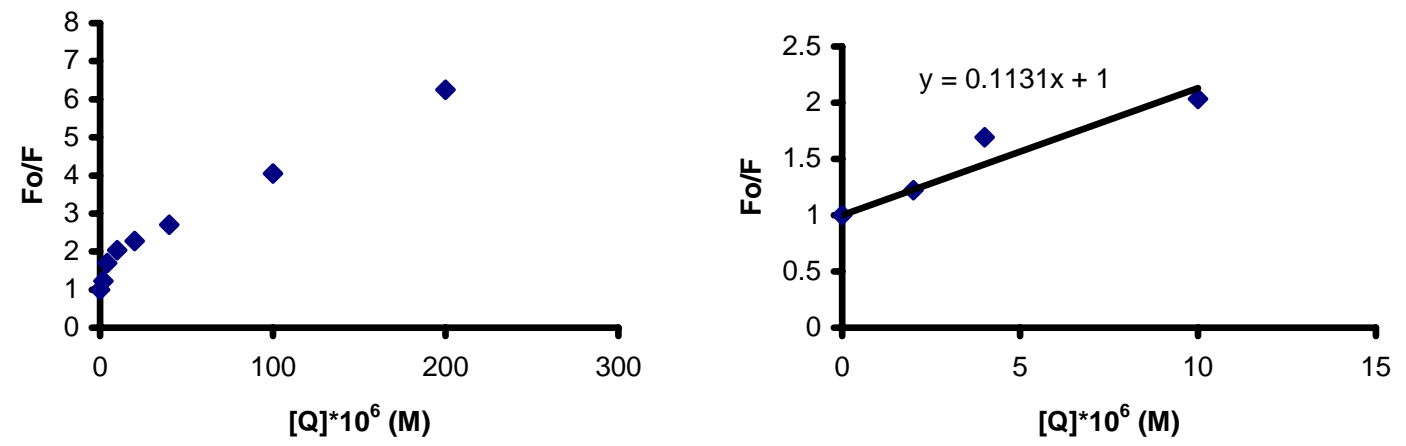

Figure 19. Fo/F plots for 3-avidin complexes with $\mathrm{Hg}^{2+}$ ions. The apparent Stern-Volmer constant ( $\left.\mathrm{K}_{\mathrm{sv}}\right)$ for $\mathrm{Hg}^{2+}$ ions based on initial linear parts is $1.1 \times 10^{5} \mathrm{M}^{-1}$. 


\section{Experiment 10. Quenching of the fluorescence of 1 by avidin.}

A small aliquot $(20-500 \mu \mathrm{L})$ of a concentrated solution of avidin $\left(1.5 \times 10^{-6} \mathrm{M}\right)$ was added to each vial containing $5 \mathrm{~mL}$ of SS1. The concentration of avidin in SS1 is $6-150 \mathrm{nM}$. The apparent Stern-Volmer constant $\left(\mathrm{K}_{\mathrm{sv}}\right)$ based on the linear part of the curve for avidin is $2.3 \times 10^{6} \mathrm{M}^{-1}$. Positively charged avidin interacts with negatively charged $\mathbf{1}$ to quench the fluorescence of $\mathbf{1}$.

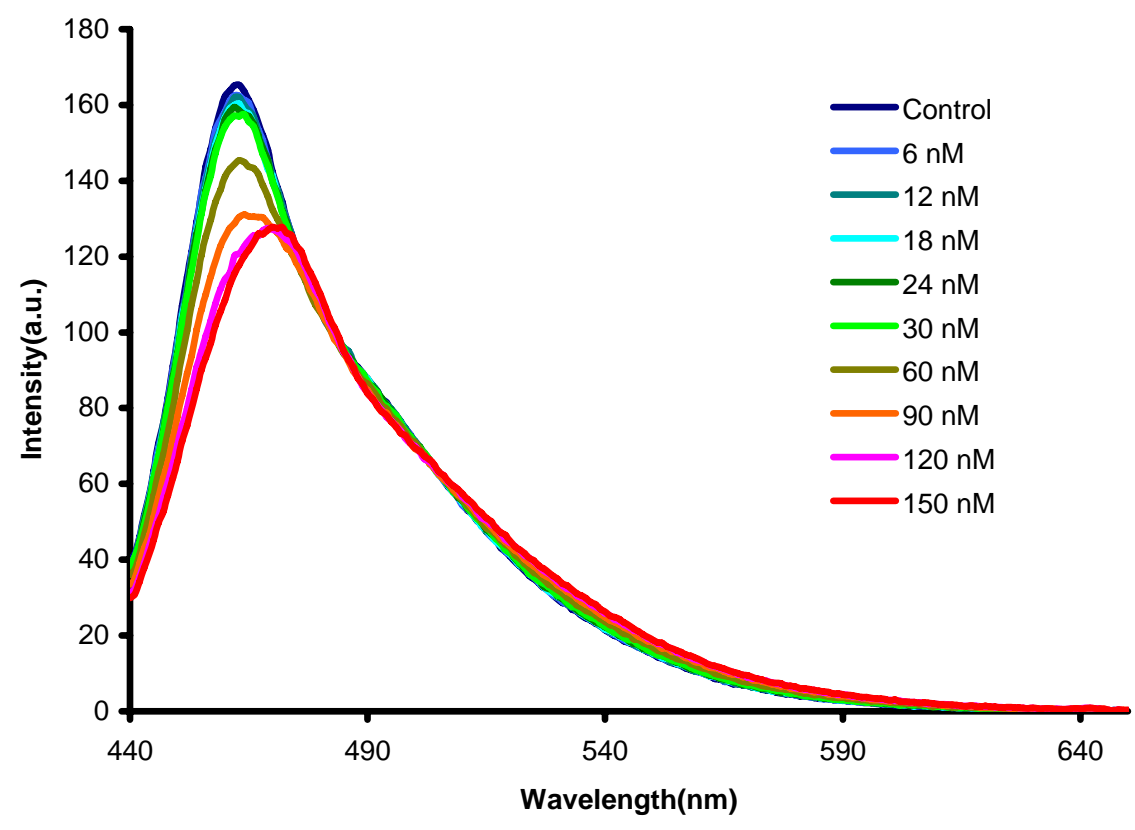

Figure 20. Emission spectra of solutions of 1 by addition of increasing concentrations of avidin.

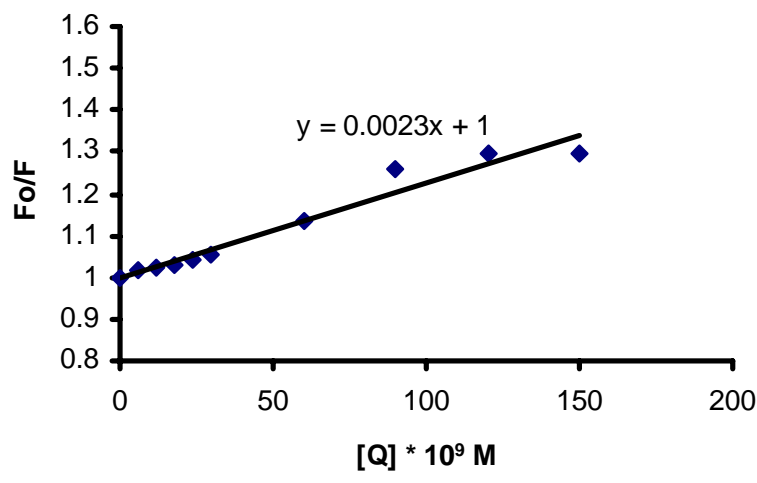

Figure 21. Fo/F plots for 1 with avidin. The apparent Stern-Volmer constant $\left(\mathrm{K}_{\mathrm{sv}}\right)$ for avidin is $2.3 \times 10^{6} \mathrm{M}^{-1}$. 
Experiment 11. Quenching of the fluorescence of PPE 1 by streptavidin-Texas Red conjugate.

A small aliquot $(50-500 \mu \mathrm{L})$ of a concentrated solution of streptavidin-Texas Red conjugate $\left(1.5 \times 10^{-6} \mathrm{M}\right)$ was added to each vial containing $5 \mathrm{~mL}$ of SS1. The concentration of streptavidinTexas Red conjugate in SS1 is $15-150 \mathrm{nM}$.

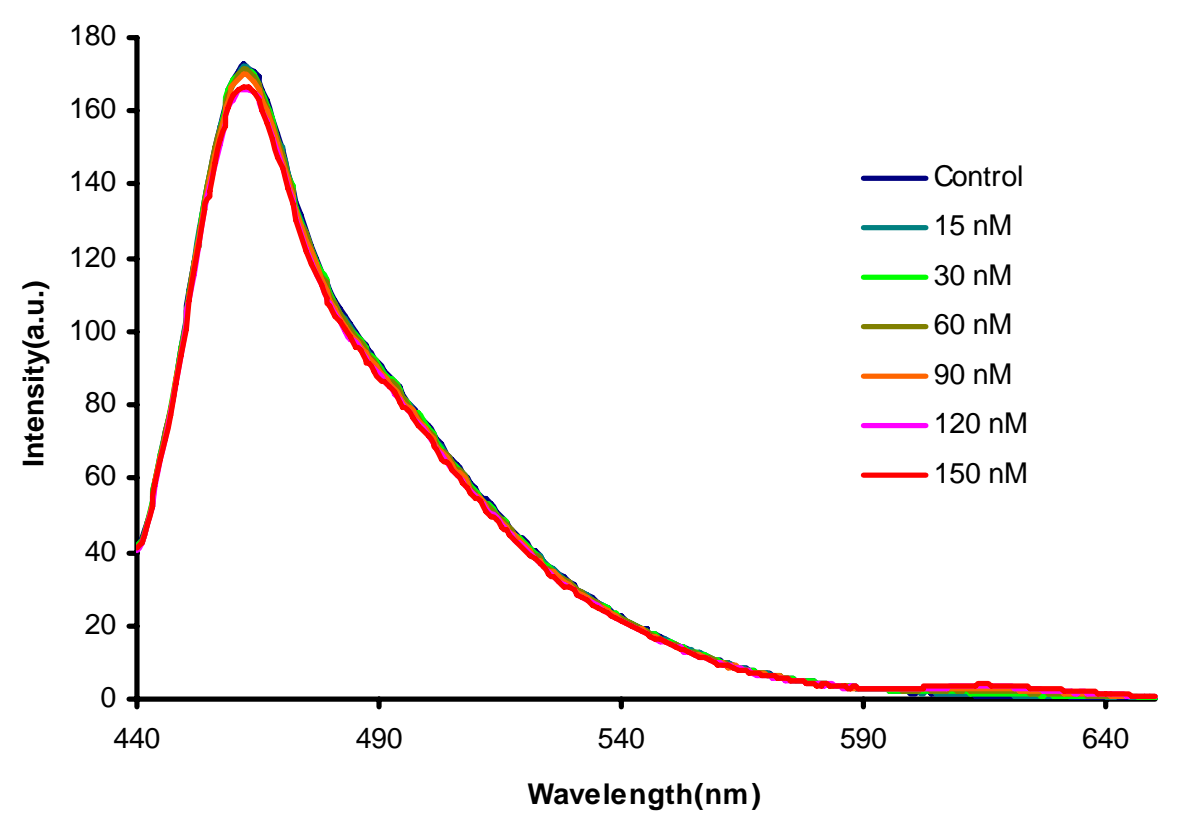

Figure 21. Emission spectra of solutions of $\mathbf{1}$ by addition of increasing concentrations of streptavidinTexas Red conjugate. 
Experiment 12. Influence of 10 different metal ions on the optical properties of PPE 4 in 0.1 $\mathrm{M}$ phosphate buffer solution at $\mathbf{p H}=\mathbf{7 . 2}$.

To investigate the sensory ability of $\mathbf{4}$ toward metal ions, we exposed them to concentrated solutions of metal ions in a $0.1 \mathrm{M}$ phosphate buffer solution $(\mathrm{pH}=7.2)$. The concentration of PPE 4 (SS4) was adjusted to $1 \mathrm{mg} / \mathrm{L}$ in a phosphate buffer solution.. Solutions of 10 metal salts were prepared at a $0.1 \mathrm{M}$ concentration: They are $\mathrm{Zn}\left(\mathrm{ClO}_{4}\right)_{2}, \mathrm{CdCl}_{2}, \mathrm{Hg}\left(\mathrm{O}-\mathrm{CO}-\mathrm{CF}_{3}\right)_{2}, \mathrm{~Pb}\left(\mathrm{NO}_{3}\right)_{2}$, $\mathrm{FeCl}_{3}, \mathrm{NiCl}_{2}, \mathrm{CoCl}_{2}, \mathrm{CuBr}_{2}, \mathrm{Ca}\left(\mathrm{NO}_{3}\right)_{2}$, and $\mathrm{Mg}(\mathrm{OTf})_{2} .20 \mu \mathrm{L}$ of each metal ion solution was added to $5 \mathrm{~mL}$ of a buffered solution of SS4. The concentration of each metal ion is $4 \times 10^{-4} \mathrm{M}$ in a buffered solution of SS4.

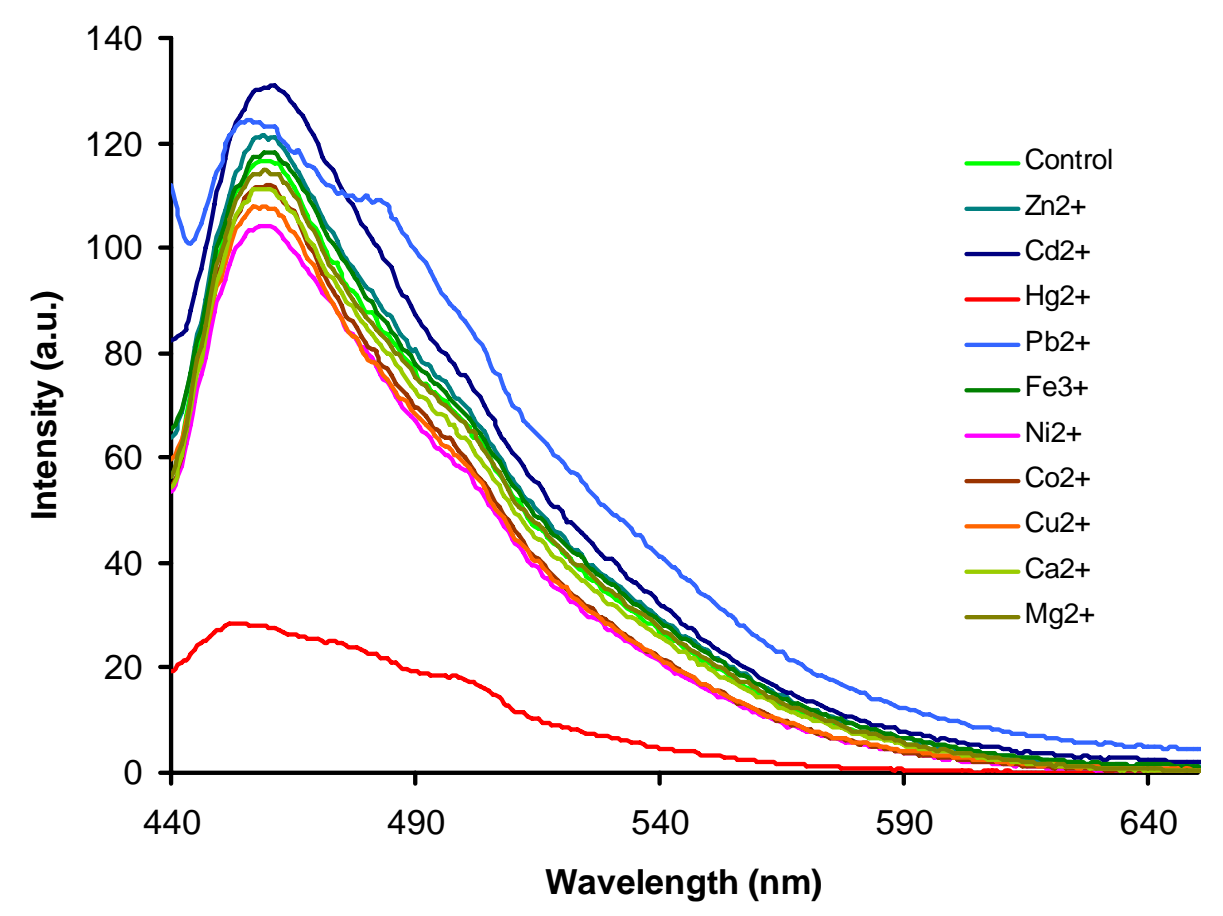

Figure 22. Emission spectra of SS4 by addition of $20 \mu \mathrm{L}$ of a $0.4 \mathrm{mM}$ solution of metal ions. Spectra show significant quenching with $\mathrm{Hg}^{2+}$ ions. 
Experiment 13. Concentration dependent quenching of the fluorescence of PPE 4 by added mercury ions.

A small aliquot $(10-100 \mu \mathrm{L})$ of concentrated solutions of $\mathrm{Hg}\left(\mathrm{O}-\mathrm{CO}-\mathrm{CF}_{3}\right)_{2}\left(1 \times 10^{-3} \mathrm{M}\right.$ and $1 \times 10^{-2}$ $\mathrm{M})$ was added to each vials containing $5 \mathrm{~mL}$ of SS4. The concentration of $\mathrm{Hg}\left(\mathrm{O}-\mathrm{CO}-\mathrm{CF}_{3}\right)_{2}$ in SS4 is $2-200 \mu \mathrm{M}$. In SS4, the apparent Stern-Volmer constant $\left(\mathrm{K}_{\mathrm{sv}}\right)$ for $\mathrm{Hg}^{2+}$ ions is $8 \times 10^{3} . \mathrm{K}_{\mathrm{sv}}$ of $\mathbf{4}$ is similar to those of $\mathbf{1}$ and $\mathbf{3}$.

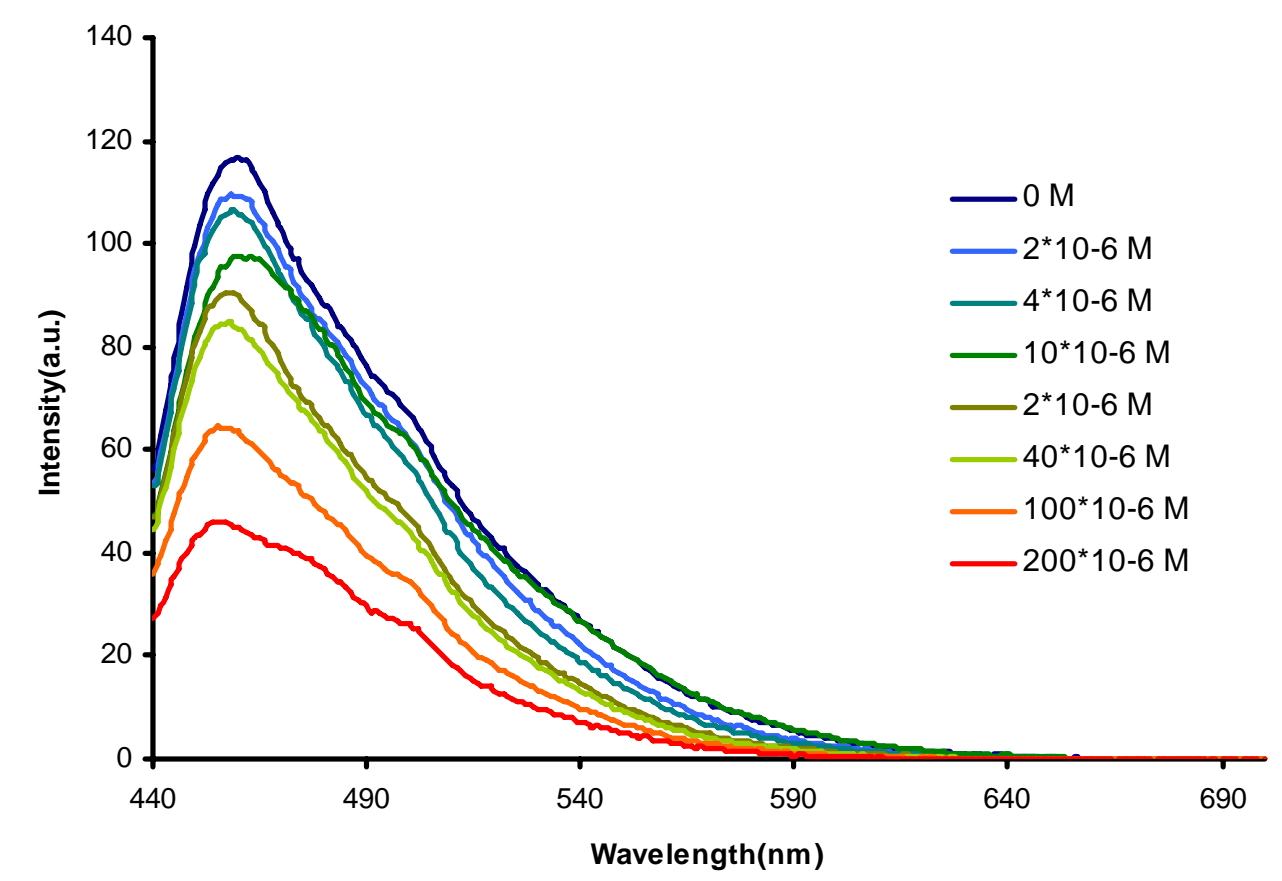

Figure 23. Emission spectra of solutions of 4 by addition of increasing concentrations of mercury ions.

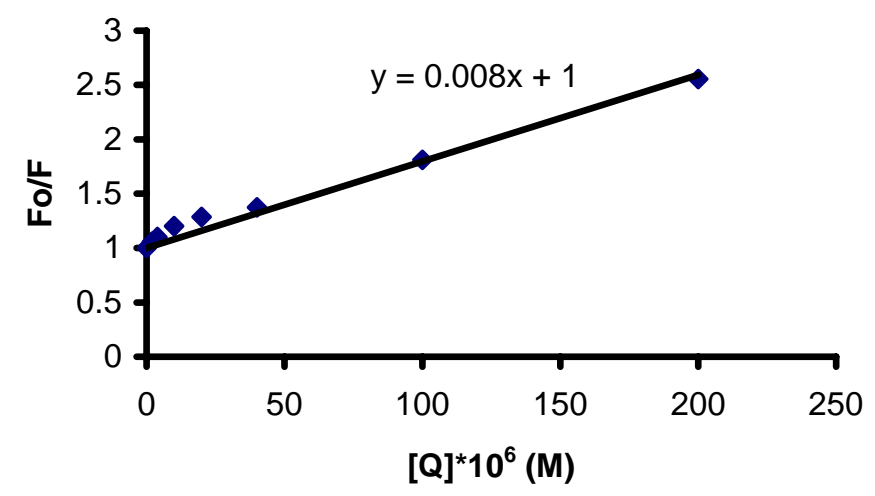

Figure 24. Fo/F plots for 4 with mercury ions. The apparent Stern-Volmer constant $\left(\mathrm{K}_{\mathrm{sv}}\right)$ for $\mathrm{Hg}^{2+}$ ions is 8 $\times 10^{3} \mathrm{M}^{-1}$. 
Experiment 14. Concentration dependent quenching of the fluorescence of PPE 3 by the addition of methyl viologen.

A small aliquot (10-100 $\mu \mathrm{L})$ of concentrated solutions of methyl viologen $\left(1 \times 10^{-3} \mathrm{M}\right.$ and $1 \times 10^{-2}$ M) was added to each vial containing $5 \mathrm{~mL}$ of SS3. The concentration of methyl viologen in SS3 is $2-200 \mu \mathrm{M}$.

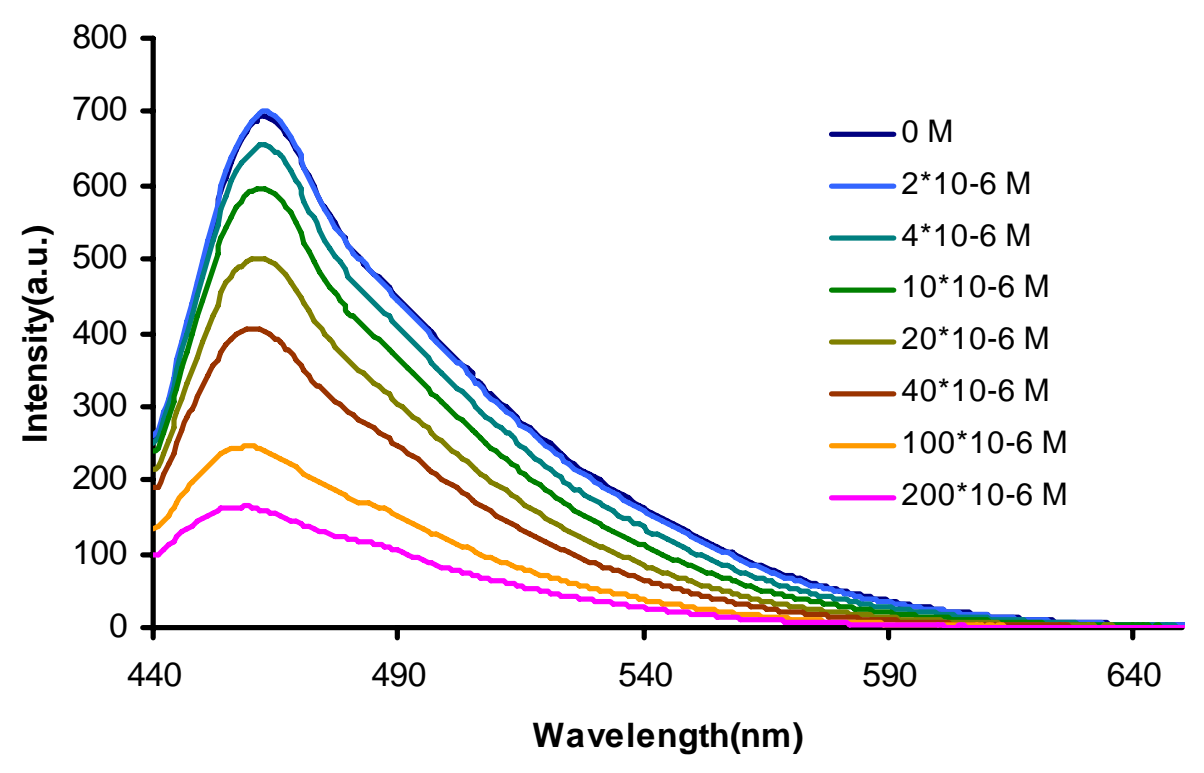

Figure 25. Emission spectra of solutions of $\mathbf{3}$ by addition of increasing concentrations of methyl viologen.

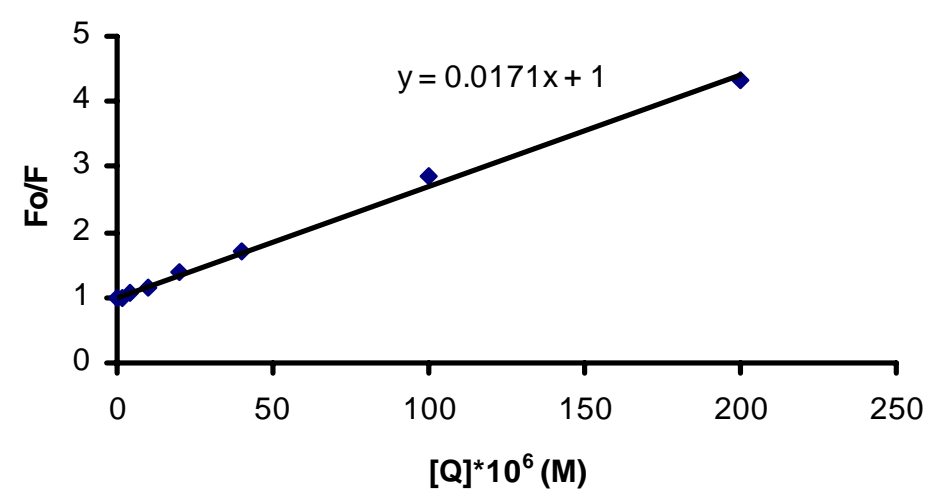

Figure 26. Fo/F plots for 3 with mercury ions. The apparent Stern-Volmer constant $\left(\mathrm{K}_{\mathrm{sv}}\right)$ for methyl viologen is $1.7 \times 10^{3} \mathrm{M}^{-1}$. 


\section{Experiment 15. Concentration dependent quenching of the fluorescence of 3-avidin complexes by the addition of methyl viologen.}

A solution of avidin was added to SS3 resulting in a $30 \mathrm{mM}$ avidin solution concentration. A small aliquot $(10-100 \mu \mathrm{L})$ of concentrated solutions of methyl viologen $\left(1 \times 10^{-3} \mathrm{M}\right.$ and $\left.1 \times 10^{-2} \mathrm{M}\right)$ was added to each vial containing $5 \mathrm{~mL}$ of 3 -avidin solution. The concentration of methyl viologen in 3-avidin solution is $2-200 \mu \mathrm{M}$.

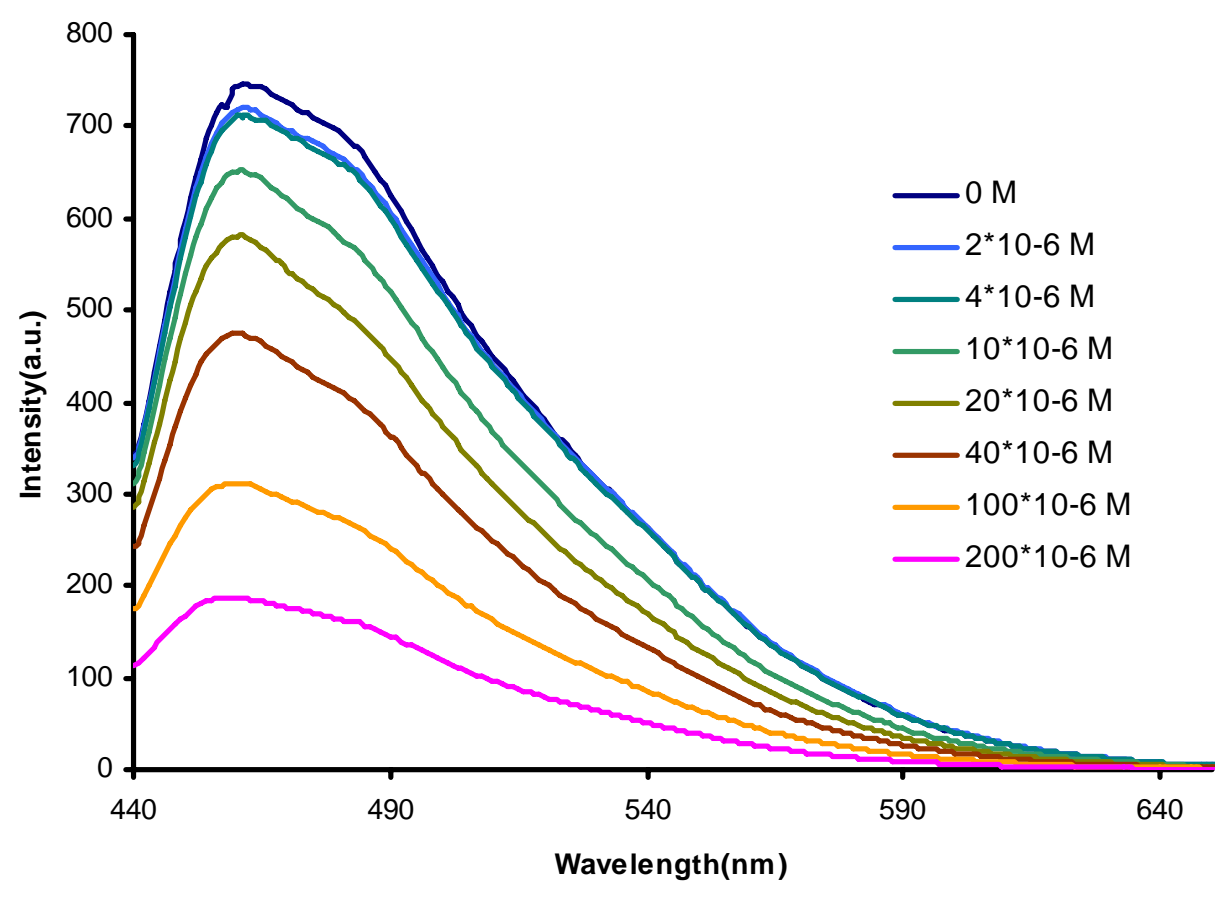

Figure 27. Emission spectra of solutions of 3-avidin complexes by addition of increasing concentrations of methyl viologen.

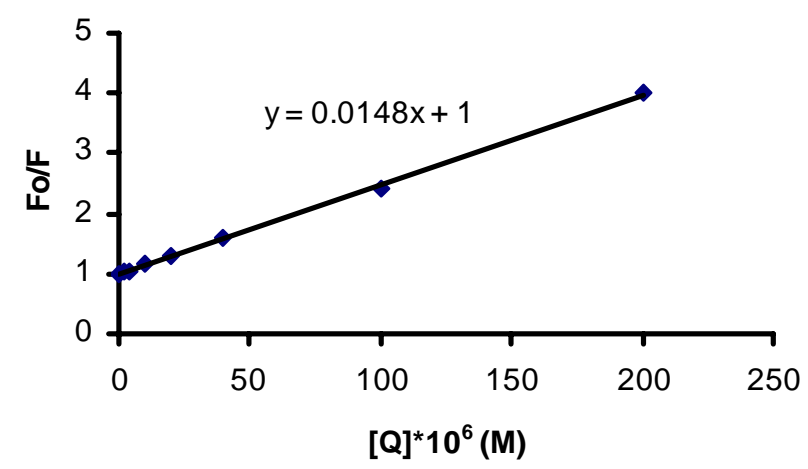

Figure 28. Fo/F plots for 3-avidin complexes with methyl viologen. The apparent Stern-Volmer constant $\left(\mathrm{K}_{\mathrm{sv}}\right)$ for methyl viologen is $1.5 \times 10^{3} \mathrm{M}^{-1}$. 


\section{Experiment 16. Quenching of the fluorescence of PPE 3 by streptavidin.}

A small aliquot $(20-500 \mu \mathrm{L})$ of a concentrated solution of streptavidin $\left(1.5 \times 10^{-6} \mathrm{M}\right)$ was added to each vial containing $5 \mathrm{~mL}$ of SS3. The concentration of streptavidin in SS3 is $6-150 \mathrm{nM}$. The apparent Stern-Volmer constant $\left(\mathrm{K}_{\mathrm{sv}}\right)$ based on the linear part of the curve for streptavidin is $6.6 \times 10^{6} \mathrm{M}^{-1}$.

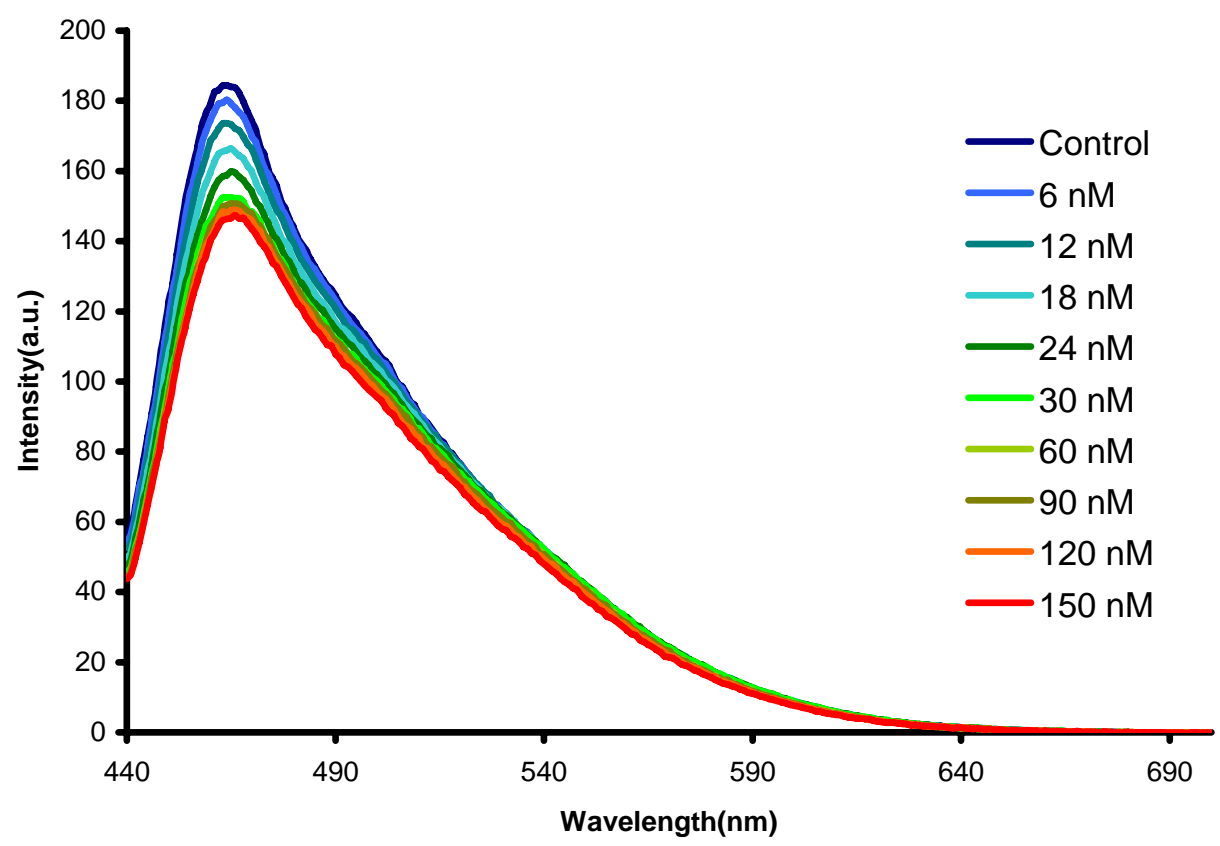

Figure 29. Emission spectra of solutions of 3 by addition of increasing concentrations of streptavidin.
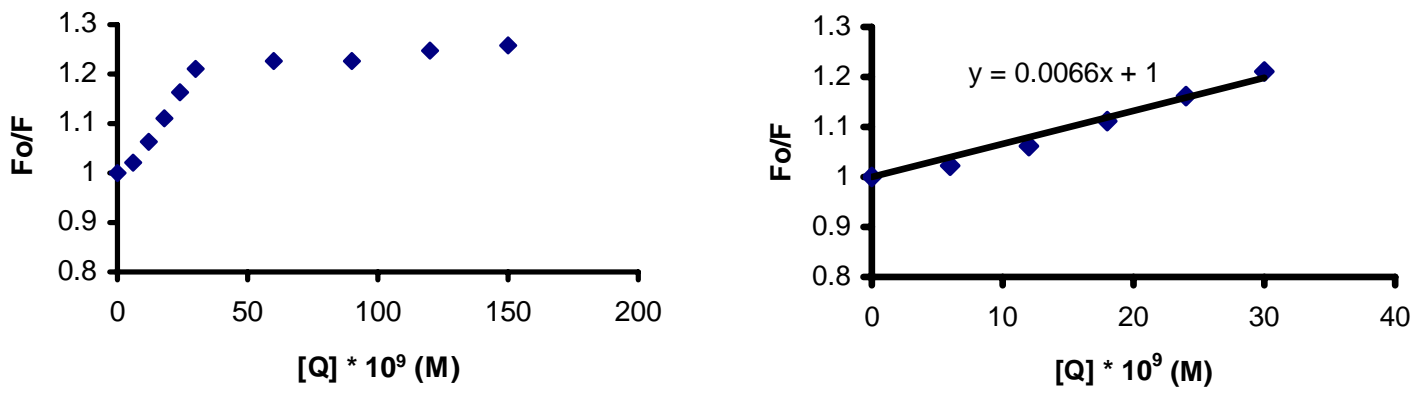

Figure 30. Fo/F plots for $\mathbf{3}$ with streptavidin. The apparent Stern-Volmer constant $\left(\mathrm{K}_{\mathrm{sv}}\right)$ for streptavidin based on initial linear parts is $6.6 \times 10^{6} \mathrm{M}^{-1}$. 
Experiment 17. Quenching of the fluorescence of 3-streptavidin complexes by the addition of mercury ions.

A solution of streptavidin was added to SS3 resulting in a $30 \mathrm{mM}$ streptavidin solution concentration. A small aliquot $(10-100 \mu \mathrm{L})$ of concentrated solutions of $\mathrm{Hg}\left(\mathrm{O}-\mathrm{CO}-\mathrm{CF}_{3}\right)_{2}\left(1 \times 10^{-3}\right.$ $\mathrm{M}$ and $\left.1 \times 10^{-2} \mathrm{M}\right)$ was added to each vials containing $5 \mathrm{~mL}$ of a 3-streptavidin solution. The concentration of $\mathrm{Hg}\left(\mathrm{O}-\mathrm{CO}-\mathrm{CF}_{3}\right)_{2}$ in 3-streptavidin solution is $2-200 \mu \mathrm{M}$. In 3-avidin complexes, the apparent Stern-Volmer constant $\left(\mathrm{K}_{\mathrm{sv}}\right)$ for $\mathrm{Hg}^{2+}$ ions based on initial linear parts is $5.5 \times 10^{4} \mathrm{M}^{-1}$.

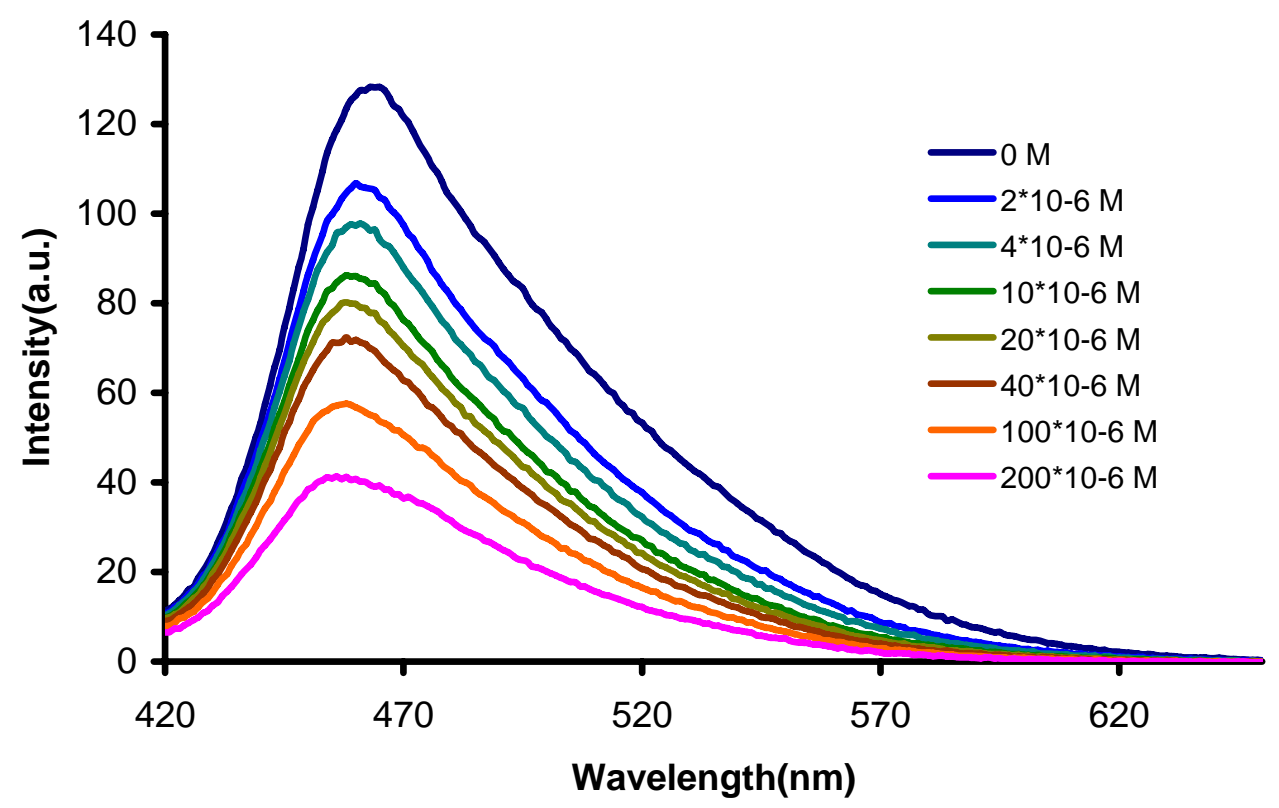

Figure 31. Emission spectra of solutions of 3-streptavidin complexes by the addition of increasing concentrations of mercury ions.
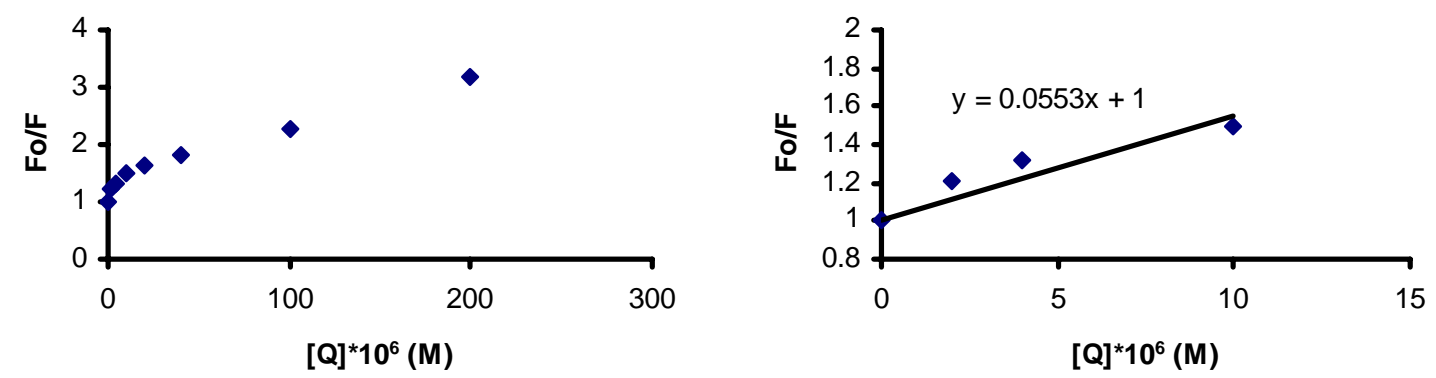

Figure 32. Fo/F plots for 3-streptavidin complexes with mercury ions. The apparent Stern-Volmer constant $\left(\mathrm{K}_{\mathrm{sv}}\right)$ for mercury ions based on initial linear parts is $5.5 \times 10^{4} \mathrm{M}^{-1}$. 
Experiment 18. Quenching of the fluorescence of 3-streptavidin complexes by added methyl viologen.

A solution of streptavidin was added to SS3 resulting in a $30 \mathrm{mM}$ streptavidin solution concentration. A small aliquot $(10-100 \mu \mathrm{L})$ of concentrated solutions of methyl viologen $\left(1 \times 10^{-3}\right.$ $\mathrm{M}$ and $\left.1 \times 10^{-2} \mathrm{M}\right)$ was added to each vial containing $5 \mathrm{~mL}$ of 3 -streptavidin solution. The concentration of methyl viologen in 3-streptavidin solution is $2-200 \mu \mathrm{M}$. In 3-streptavidin complexes, the apparent Stern-Volmer constant $\left(\mathrm{K}_{\mathrm{sv}}\right)$ for methyl viologen is $2.3 \times 10^{3} \mathrm{M}^{-1}$.

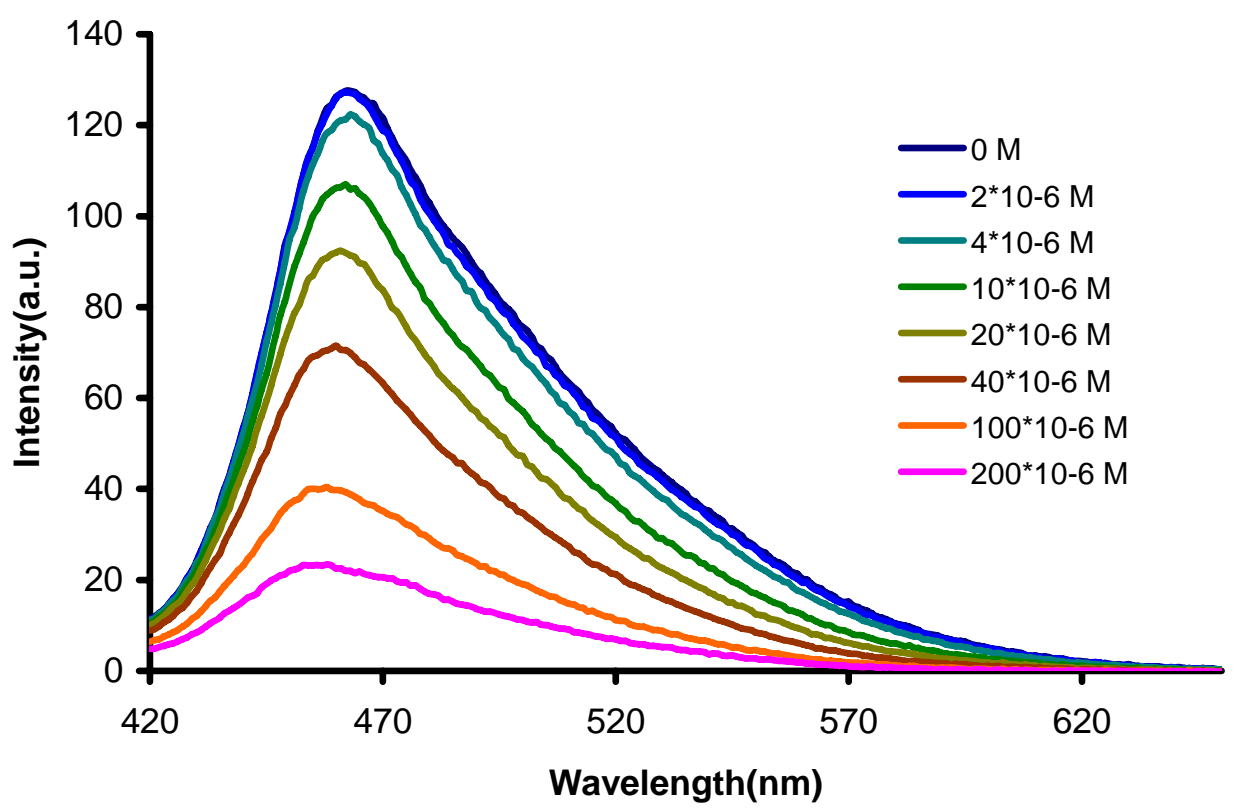

Figure 33. Emission spectra of solutions of 3-streptavidin complexes by addition of increasing concentrations of methyl viologen.

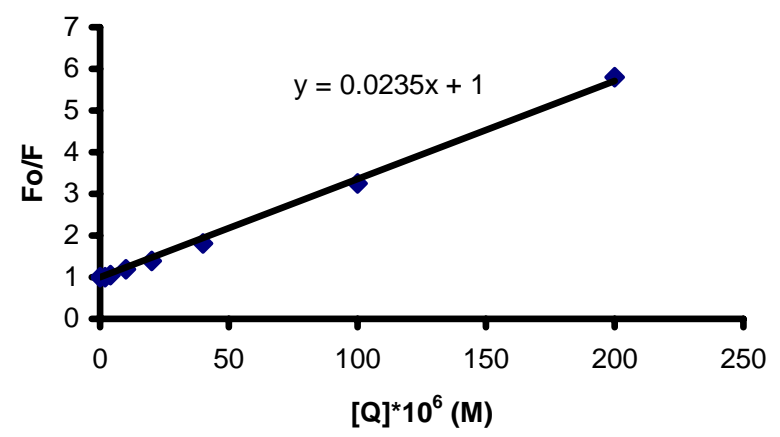

Figure 34. Fo/F plots for 3-avidin complexes with methyl viologen. The apparent Stern-Volmer constant $\left(K_{\mathrm{sv}}\right)$ for methyl viologen is $2.3 \times 10^{3} \mathrm{M}^{-1}$. 


\section{References}

1. Kim, I. B.; Dunkhorst, A.; Gilbert, J.; Bunz, U. H. F. Macromolecules 2005, 38, 45604562 .

2. Kim, I. B.; Bunz, U. H. F. J. Am. Chem. Soc. 2006, 128, 2818-2819. 